\title{
Risk Factors for Unhealthy Weight Gain and Obesity among Children with Autism Spectrum Disorder
}

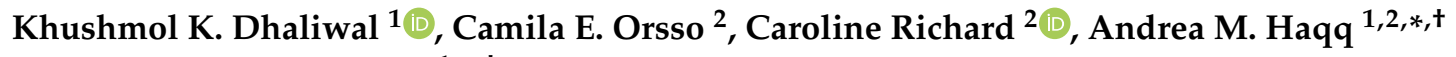 \\ and Lonnie Zwaigenbaum ${ }^{1, *,+}$ \\ 1 Department of Pediatrics, Faculty of Medicine and Dentistry, University of Alberta, 1140587 Avenue, \\ Edmonton, AB T6G 1C9, Canada \\ 2 Department of Agricultural, Food and Nutritional Science, Faculty of Agricultural, Life \& Environmental \\ Sciences, University of Alberta, 2-06 Agriculture Forestry Centre, Edmonton, AB T6G 2P5, Canada \\ * Correspondence: haqq@ualberta.ca (A.M.H.); lonniez@ualberta.ca (L.Z.); \\ Tel.: +1-780-492-0015 (A.M.H.); +1-780-735-8280 (L.Z.) \\ + Co-senior authors.
}

Received: 7 June 2019; Accepted: 3 July 2019; Published: 4 July 2019

\begin{abstract}
Autism Spectrum Disorder (ASD) is a developmental disorder characterized by social and communication deficits and repetitive behaviors. Children with ASD are also at a higher risk for developing overweight or obesity than children with typical development (TD). Childhood obesity has been associated with adverse health outcomes, including insulin resistance, diabetes, heart disease, and certain cancers. Importantly some key factors that play a mediating role in these higher rates of obesity include lifestyle factors and biological influences, as well as secondary comorbidities and medications. This review summarizes current knowledge about behavioral and lifestyle factors that could contribute to unhealthy weight gain in children with ASD, as well as the current state of knowledge of emerging risk factors such as the possible influence of sleep problems, the gut microbiome, endocrine influences and maternal metabolic disorders. We also discuss some of the clinical implications of these risk factors and areas for future research.
\end{abstract}

Keywords: Autism spectrum disorder; ASD; Obesity; Overweight; Body mass index; BMI

\section{Introduction}

Autism Spectrum Disorder (ASD) is a developmental disorder characterized by social and communication impairments and repetitive behaviors [1,2]; the global prevalence is estimated at 1 in 160 children [3], although current North American estimates are around 1 in 60 children [4,5]. Children with ASD are also often at an increased risk for becoming obese (i.e., body mass index [BMI]-for-age $\geq 95$ th percentile) or overweight (i.e., BMI-for-age $\geq 85$ th percentile) than children with typical development (TD) [6-8]. These BMI levels are associated with adverse health outcomes, including insulin resistance, diabetes, heart disease, and certain cancers $[9,10]$. Obesity in childhood can also adversely affect physical, emotional, and social functioning, as well as academic performance [11], which might compound disability and reduced quality of life associated with ASD.

Some known key factors that may play a mediating role in the higher rates of obesity observed in children with ASD include eating behaviors [12], lifestyle [13], secondary comorbidities [14], and medications usage [15]. There is also evidence showing that reduced gut microbiota diversity [16,17], hormonal imbalances [18-20], and maternal metabolic disorders [21,22] may influence the development of either ASD or childhood obesity alone. However, it is yet not clear whether and to what extent these emerging factors are contributors for unhealthy weight gain and obesity among children with ASD. We define emerging risk factors as factors independently associated with increased risk for both obesity 
and ASD that have not yet been studied as risk factors for unhealthy weight gain and obesity among children with ASD.

Preventing unhealthy weight gain and obesity among children with ASD is crucial, as obesity affects overall children's health and well-being and often persists into adulthood [23]. To develop appropriate strategies with increased efficacy, a comprehensive understanding of the risk factors for obesity development in ASD is required. Therefore, the purpose of this narrative review is to critically summarize current knowledge of behavioral, lifestyle, and biological factors potentially contributing to unhealthy weight gain in children with ASD. We also discuss the current state of knowledge of novel emerging risk factors for pediatric obesity in ASD.

Briefly, studies discussed in this manuscript were obtained after conducting a literature search in the main databases MEDLINE, CINAHL, and Google Scholar from inception to May 2019. We searched for multiple variations of the disorder (e.g., autism, autism spectrum disorder, Asperger syndrome) and keywords related to each section of this manuscript (e.g., obesity, overweight, weight gain, oral sensitivities, food selectivity, physical activity, recreational activities). Search was limited to articles in English and reference lists of selected articles, systematic reviews, and meta-analyses were manually reviewed to identify additional relevant articles. A critical synthesis of the literature is presented throughout the main text, describing the limitations of included articles.

\section{Feeding Behavior}

Reported rates of atypical behavior related to sensory experiences are high among children with ASD [24]. Compared to sex- and age-matched controls, individuals with autism aged 3 to 56 years old exhibited an abnormal oral sensory processing, characterized by either greater oral seeking (e.g., child putting everything into their mouth) or oral defensiveness (e.g., avoidance of certain textures and tastes and/or only eating a limited variety of foods) $[25,26]$. Interestingly, age-group analyses revealed reductions in the differences of sensory processing difficulties between ASD and TD children over time, suggesting that children are the most affected ones [25]. These sensory difficulties can lead to atypical eating behaviors and feeding practices in ASD, as children may avoid certain foods due to texture and/or taste and only eat a limited variety of foods (i.e., food selectivity). In fact, a recent meta-analysis identified that children with ASD experienced about five times more feeding problems and exhibited lower intake of calcium than TD children [27]. Thus, children with ASD may be at risk for inadequate micronutrient intake [28].

Although several studies characterizing feeding behaviors in children with ASD have evaluated the prevalence of overweight and obesity, few have attempted to investigate whether differences in feeding behavior are related to body weight categories. To our knowledge, only one study found that male children with ASD, who were overweight or obese, had more problematic mealtime and feeding behaviors than overweight or obese TD children, as indicated by the higher scores on a Behavior Pediatrics Feeding Assessment Scale (BPFA) in the ASD group [29]. There were no differences in BPFA scores between children with ASD and TD children, of either thin or adequate weight status [29]. However, another study of younger male and female children described no differences in feeding behaviors (assessed by questionnaire depicting oral function, eating problems, and others) across weight categories [30]. It is important to note that the sample populations in these two studies differed by age, sex, and cultural origins (Brazilian vs. Chinese), limiting comparison. Moreover, the second study found that children with ASD actually had lower mean BMI z-scores than TD children. Another approach to assessing whether feeding behaviors play a role in obesity is to examine within sample correlations. For example, one study found no significant association between dietary patterns and BMI z-score in children with ASD aged 3 to 11 years [31]. Therefore, it is not clear from the current literature whether feeding behavior is, and to what degree, a contributor to excess weight gain in children and adolescents with ASD. We speculate that abnormal feeding behaviors and/or dietary intake could influence weight status. For example, a study found children with ASD tended to consume more sweetened beverages and snacks foods (chips, candy, etc.) [31]. Thus, although children may be eating 
a limited variety of foods, these may be unhealthier overall (driving weight gain). However, picky eating could also result in weight loss [32].

Overall total energy intake and macronutrient distribution could also contribute to weight gain among children with ASD. With regard to total energy intake, two recent meta-analyses included three-day food record and food frequency questionnaires (FFQs) data from six prospective studies [27] and 14 observational studies $[27,33]$. No significant overall differences in total energy intake were detected between children with ASD and TD children [33]. It is also important to consider macronutrient distribution, which can lead to variations in body weight and cardiometabolic risk profiles [34,35]. However, the optimal macronutrient distribution for improving the weight status of children and adolescents is not yet understood [36]. Data from the same two meta-analyses that examined energy intake also assessed macronutrient intake, finding no significant difference in the intake of carbohydrates and fats between children with ASD and TD children [27,33]. Intake also tended to be within the acceptable macronutrient distribution range (AMDR) [8,33]. Children with ASD consumed less protein than TD children $[27,33]$, but both groups were consuming more protein than currently recommended for a healthy diet [33].

Micronutrients are also integral to maintaining healthy body weight and have important functions in various metabolic pathways [37]. Children with ASD are often placed on restrictive diets, such as the gluten-free, casein-free (GFCF) diet [38], which may reduce intake of certain micronutrients. GFCF diets have been considered as a possible therapeutic intervention for some of the behavioral symptoms of ASD; however, evidence is lacking [39]. A recent systematic review identified three studies showing that nutrient inadequacies tended to remain among children with ASD even after controlling for common elimination diets, such as GFCF regimens [27,40-42]. Evidence suggests that deficiencies of vitamin A, vitamin D, B-complex vitamins, calcium, and zinc may be associated with increased fat deposition [43]. Findings from a meta-analysis confirm intake deficiencies in calcium and vitamin D in children with ASD relative to TD children and dietary intake recommendations [33]. However, the causality in the relationship between micronutrient intake and fat deposition remains unestablished [43]. Future studies should also take into account the use of dietary supplements, which are commonly offered to children with ASD [39].

In addition to these feeding behaviors and patterns, anecdotal reports indicate that children with ASD may limit their intake of fruits and vegetables due to factors such as taste and texture [42]. The consumption of fruits and vegetables has shown to be inversely associated with weight change and body adiposity $[44,45]$. However, studies based on prospective three-day food records generally demonstrate no difference in the intake of vegetables or fruits between children with ASD and TD children $[40,46]$, with both groups consuming below the recommendations for vegetable intake [46]. In contrast, a systematic review of studies using FFQs (which assess subjective, longer-term eating patterns) indicated that children with ASD consume fewer daily servings of fruits and vegetables [31]. Likewise, Bandini et al. found that FFQ data revealed children with ASD refuse more vegetables than TD children [42]. In agreement with this, a study found that food refusal in children with ASD may in some cases be due to a bitter taste sensitivity associated with the TAS2R38 genotype [47]. Although little research has investigated the implications of polymorphisms in taste receptors and feeding behaviors in ASD, previous research has demonstrated that TD children exhibit two sensitive alleles for bitter taste had a lower threshold concentration to detected sucrose and a greater sugar consumption compared to children with less sensitive alleles [48]. Thus, future research into the prevalence of genetic variants of taste receptors in ASD may help to provide further insight into particular eating behavior differences, such as vegetable intake, among groups [49].

Overall, much of the recent literature seems to suggest that among those with ASD, overall intake of energy and macronutrients is fairly comparable to the TD population. These findings, however, must be interpreted with caution, because methods for collecting dietary information are often limited by variances in day-to-day food intake [50], under-reporting of energy intake [51], and behavioral reactions to measurement (e.g., changes in food intake, especially in individuals with obesity) [52]. 
Furthermore, although FFQs are designed to capture long-term eating habits, they include a limited number of foods and both FFQs and three-day food recalls are prone to recall bias [53]. Thus, the relationship between dietary intake and obesity rates may be clouded by limitations in these commonly used measures. In addition, parents of children with ASD may be more attuned to their children's food selectivity behaviors, than parents of TD children, influencing diet data collection. Future studies using direct methods, such as doubly labeled water, to measure energy expenditure and energy intake, may be more informative [52,54]. Additionally, researchers should further elucidate differences in dietary intake within the ASD group based on oral sensitivities, dietary restrictions, and secondary comorbidities (e.g., GI disorders), and take into account age- and possibly sex-related differences. Eating disorders, such as anorexia nervosa, can also impact feeding behaviors and studies have found comorbidities between eating disorders and ASD, specifically among females [55,56]. Studies suggest that specific behavioral phenotypes, such as rigid and repetitive behaviors and social anhedonia, overlap among both conditions [56,57]. This further highlights the importance of stratifying feeding behaviors based on sex differences.

\section{Physical Activity and Sedentary Behavior}

School-based or extracurricular programs provide opportunities for children to be physically active and engage with peers. Physical activity (PA) is considered a protective factor in maintaining a healthy body weight and preventing obesity [58]. However, opportunities for PA may be limited in children with ASD due to social and behavioral challenges [59,60], as well as motor deficits [61-63].

For optimal health benefits [64], the U.S. Department of Health and Human Services Office of Disease Prevention and Health Promotion suggests that children between the ages of 6 and 17 years should engage in moderate- to vigorous-intensity physical activity (MVPA) for at least $60 \mathrm{~min}, 3$ days per week [65]. Studies that have assessed intensity and frequency of PA in children and adolescents with ASD are summarized in Table 1. Studies comparing the daily time spent in MVPA, as measured by accelerometers, between children with and without ASD have yielded mixed findings. For example, while Bandini et al. reported similar daily MVPA in children with ASD and TD children [66], Stanish et al. found that children with ASD who are younger than 16 years old spent less time engaged in MVPA; but for those adolescents over 16 years, the difference in MVPA was not significant [67]. In contrast, a systematic review found a consistently negative association between PA and age [68]. The discrepancies in these findings suggest that longitudinal studies would enhance the understanding on whether age influences PA patterns. Notably, both children with ASD [67] and TD children [69] were unlikely to meet the recommendations for MVPA. 
Table 1. Physical activity

\begin{tabular}{|c|c|c|c|c|c|c|}
\hline Study & Design & Study Group & Control Group & Measure & Result & BMI \\
\hline $\begin{array}{l}\text { Bandini et } \\
\text { al. [66] }\end{array}$ & Cross-sectional & $\begin{array}{l}53 \text { male and female } \\
\text { children with ASD } \\
\text { (age: } 3-11 \text { years) }\end{array}$ & $\begin{array}{l}58 \text { male and female } \\
\text { TD children (age: } \\
3-11 \text { years) }\end{array}$ & $\begin{array}{l}\text { Accelerometer data } \\
\text { Questionnaire (parent } \\
\text { report on type and } \\
\text { frequency) }\end{array}$ & $\begin{array}{l}\text { Similar daily MVPA for both } \\
\text { groups (ASD: } 50.0 \text { min/day; TD: } \\
57.1 \text { min/day). } \\
\text { Children with ASD participate in } \\
\text { significantly fewer types of } \\
\text { physical activities ( } 6.9 \text { vs. } 9.6, p< \\
0.0001 \text { ) and spend less time } \\
\text { annually participating in these } \\
\text { activities than TD children (158 } \\
\text { vs. } 225 \mathrm{~h} \text { per year, } p<0.0001) .\end{array}$ & $\begin{array}{l}\text { No significant difference } \\
\text { between the two groups } \\
\text { BMI-z score not significantly } \\
\text { associated with percent time } \\
\text { spent in MVPA }\end{array}$ \\
\hline $\begin{array}{l}\text { Stanish et } \\
\text { al. [67] }\end{array}$ & Cross-sectional & $\begin{array}{l}35 \text { male and female } \\
\text { children with ASD } \\
\text { (age: } 13-21 \text { years) }\end{array}$ & $\begin{array}{l}60 \text { male and female } \\
\text { TD children (age: } \\
13-18 \text { years) }\end{array}$ & $\begin{array}{l}\text { Accelerometer data } \\
\text { (total average daily } \\
\text { PA) } \\
\text { Questionnaire (type } \\
\text { and frequency of PA) }\end{array}$ & $\begin{array}{l}\text { Children with ASD who are } \\
\text { younger than } 16 \text { spend less time } \\
\text { in MVPA (ASD: } 26 \text { min/day vs. } \\
51 \text { min/day) and participate in } \\
\text { fewer activities. } \\
\text { No significant difference in } \\
\text { MVPA among individuals older } \\
\text { than } 16 \text { years. }\end{array}$ & $\mathrm{N} / \mathrm{A}$ \\
\hline $\begin{array}{l}\text { Must et al. } \\
{[70]}\end{array}$ & Cross-sectional & $\begin{array}{l}53 \text { children with ASD } \\
\text { (age: } 3-11 \text { years) }\end{array}$ & $\begin{array}{l}58 \text { TD children (age: } \\
3-11 \text { years) }\end{array}$ & $\begin{array}{l}\text { Parent report } \\
\text { questionnaire (type } \\
\text { and frequency) }\end{array}$ & $\begin{array}{l}\text { An inverse correlation between } \\
\text { the total number of barriers } \\
\text { reported and the number of PA } \\
\text { hours per year (ASD: } 119 \mathrm{~h} \text {; TD } \\
169 \mathrm{~h} ; p<0.05 \text { ). }\end{array}$ & $\begin{array}{l}\text { No significant difference in } \\
\text { BMI percentiles }\end{array}$ \\
\hline $\begin{array}{l}\text { McCoy et } \\
\text { al. [71] }\end{array}$ & Cross-sectional & $\begin{array}{l}915 \text { male and female } \\
\text { children with ASD } \\
\text { (age: } 10-17 \text { years) }\end{array}$ & $\begin{array}{l}41,879 \text { male and } \\
\text { female TD children } \\
\text { from the 2011-2012 } \\
\text { National Survey of } \\
\text { Children's Health } \\
\text { (age: } 10-17 \text { years) }\end{array}$ & $\begin{array}{l}\text { Parent report } \\
\text { questionnaire (type } \\
\text { and frequency) }\end{array}$ & $\begin{array}{l}\text { Adolescents with ASD are less } \\
\text { likely to engage in PA }(p<0.05) \\
\text { Higher autism severity is } \\
\text { associated with increased odds } \\
\text { of being obese (OR: } 2.8 ; 95 \% \text { CI: } \\
1.39,3.74) \text {, and decreased odds of } \\
\text { PA (OR: } 0.30 ; 95 \% \text { CI: } 0.20,0.46) \text {. }\end{array}$ & $\begin{array}{l}\text { Adolescents with ASD are } \\
\text { more likely to be overweight } \\
\text { and obese (ASD: } 22 \% \text {; TD } \\
14.1 \% \text {; } p<0.05 \text { ). }\end{array}$ \\
\hline $\begin{array}{l}\text { Healy et al. } \\
{[72]}\end{array}$ & Cross-sectional & $\begin{array}{l}67 \text { male and female } \\
\text { children with ASD } \\
\text { (age: } 13 \text { years) }\end{array}$ & $\begin{array}{l}74 \text { randomly selected } \\
\text { male and female TD } \\
\text { children (age: } \\
13 \text { years) }\end{array}$ & $\begin{array}{l}\text { Parent report } \\
\text { questionnaire (type } \\
\text { and frequency) }\end{array}$ & $\begin{array}{l}\text { Significantly lower participation } \\
\text { in MVPA }(p<0.001) \text { and sports } \\
\text { reported for children with ASD } \\
(p<0.001)\end{array}$ & $\begin{array}{l}\text { No statistically significant } \\
\text { difference between the two } \\
\text { groups in mean BMI and } \\
\text { overweight/obese status. }\end{array}$ \\
\hline
\end{tabular}

Abbreviations: ASD, Autism Spectrum Disorder; TD, Typically Developing; MVPA, Medium-Vigorous Physical Activity; BMI, Body Mass Index. 
Studies utilizing parent report questionnaires generally show that children with ASD spend less time engaged in PA than TD children [70-72]. Although questionnaires are more feasible than objective measures given the associated time demands and costs, parent-reports often underestimate PA [73]. In the Bandini et al. study, parents reported that their children with ASD spent significantly less time in PA annually (158 vs. $225 \mathrm{~h}$ per year) and participated in fewer types of PA, but no differences in PA between children with ASD and TD children were observed based on accelerometry data [66]. Parents of children with ASD also report more barriers to PA (e.g., increased needs for supervision), which could influence their estimates of overall PA [70]. Moreover, a weak to moderate correlation has been found between parent reports of children's PA and accelerometer-measured activity, depending on type of activity and age group [73]. It is possible that children react to being monitored by increasing their PA [74]; on the other hand, social desirability bias could cause parents to under- or over-report their children's PA based on weight status [75].

Another important variable to consider is sedentary behavior (SB), which is defined as resting behavior with very little expenditure of energy [76]. Factors contributing to prolonged SB in children may include increased access to television, computers, and phones [77,78]. Prolonged SB has long-term health consequences, such as increased body weight, cardiovascular diseases, and type 2 diabetes $[79,80]$. In a recent systematic review, only two of six studies comparing the prevalence rates of SB reported greater participation in SB by children with ASD than TD children [68]. However, children with ASD (aged 8-18 years old) spent 62\% more time on screen activities compared to their TD siblings, as reported by parents [81]. Furthermore, children with ASD spent more hours per day playing video games (both boys and girls), but spent less time using social media or playing interactive video games [81,82].

Overall, the relationships between time spent in MVPA or SB and the propensity for children with ASD to be overweight or obese were not directly investigated in the reviewed studies. It is important to note that ASD severity may influence these relationships by affecting behavior as well as social and motor functioning [83]. Indeed, McCoy et al. found an association between higher parent-reported levels of autism severity, increased odds of being obese, and decreased odds of PA [71]. In the future, research based on objective measures of MVPA and SB (e.g., accelerometer data) could yield insights into differences in these variables between children with ASD and TD children. Further sample stratification based on ASD severity could further clarify how symptoms moderate the relationship between PA and SB among children with ASD.

\section{Genetics}

Genetic vulnerabilities and syndromic causes of ASD and obesity have been explored extensively, albeit independently. Both conditions are heritable; thus, understanding possible shared genetic links may yield insights into their interplay. Specifically, sibling and twin studies have shown that ASD tends to run in families [84,85]. Likewise, genetics also play a role in childhood obesity [86]. When compared to adopted siblings, the risk of being obese is higher among individuals with affected siblings and parents who are already obese [87]. Because both ASD and obesity have heritable components, investigation of any genetic overlap in their pathways may help explain the higher rates of obesity among individuals with ASD.

Sharma et al. hypothesized that a common molecular pathway may contribute to the pathogenesis of ASD and obesity, as a pathway-based analysis revealed 36 common genes between these two conditions [88]. Specifically, one study has shown that ASD, Attention Deficit Hyperactivity Disorder (ADHD), developmental delays and obesity are highly associated with a microdeletion involving 11p14.1 [89]. Furthermore, deletions in 16p11.2 were associated with genetic vulnerabilities related to both obesity and ASD [90,91]. More recently, in a genetic analysis of very obese children with ASD, Cortes and Wevrick focused on de novo mutations and found that very obese ASD probands had loss of function mutations in DNMT3A and POGZ [92].

In addition, Prader-Willi Syndrome (PWS) is a genetic disorder caused by paternal 15q11-13 deletions [93]. PWS is characterized by hyperphagia, elevated ghrelin concentrations, and increased risk for obesity $[93,94]$. PWS is also associated with higher rates of social-communication impairments 
and repetitive behaviors [95], although the degree to which symptoms meet diagnostic criteria for ASD varies across studies, emphasizing that ASD symptom measures require careful consideration of developmental profile and overall clinical context $[95,96]$. That said, genetic mechanisms underlying the association between Prader Willi and ASD may underlie obesity risk related to hyperphagia in a subset of individuals with ASD [97].

In summary, although evidence indicates that certain genetic vulnerabilities are associated with both ASD and obesity, there is a need to further investigation, such as pathway-based analyses to reveal how genetics influence the complex etiologies of both conditions. In addition, it is not currently clear what proportion of children with ASD and obesity would be accounted for by these rare genetic variants; future efforts to parse the relative contribution of genetic versus non-genetic associations would provide important insights into this topic. Genetic testing, in the form of clinical microarrays, are increasingly becoming standard of practice for ASD diagnosis [98] and determining whether there are deletions in areas such as 16p11.2 may allow for early interventions and targeted molecular therapy, with potential to prevent obesity in children with ASD.

\section{Medications}

Comorbid conditions, such as ADHD and depression, often manifest in ASD [99]. To manage these and other behavioral symptoms, psychotropics including stimulants, selective serotonin reuptake inhibitors (SSRIs), and antipsychotics are often prescribed [100]. The prescription rate of these drugs in children with ASD has been reported at 27-64\% (median 41.9\%) [101-104].

A 2016 meta-analysis by Park found that 1 in 6 children with ASD were prescribed anti-psychotic medication [105]. Second-generation anti-psychotics (SGA) such as risperidone and aripiprazole, are often prescribed to alleviate behavioral symptoms comorbid with ASD such as hyperactivity, irritability and aggression [106,107], but are associated with substantial weight gain [15,106]. A systematic review of seven randomized controlled trials (RCTs) of risperidone use among children and adolescents with ASD, revealed weight gain as an adverse event [15]. Furthermore, dose-related increases in blood glucose, insulin, and leptin have been reported [108] and metabolic changes (e.g., leptin) track closely with changes in fat mass [109]. Furthermore, a systematic review looking at two RCTs of apriprazole use in children with ASD reported a mean difference of $1.13 \mathrm{~kg}$ of weight gain in children using apriprazole compared to a placebo after 8 weeks of treatment [110]. Other commonly prescribed antipsychotics in ASD are olanzapine and clozapine [111,112]. A 2014 meta-analysis found that olanzapine and clozapine were also both associated with severe weight gain [113]. The mechanism of action behind weight gain associated with atypical antipsychotics relates in part to serotonin receptor blockade and reduction in dopamine (D2) receptor-mediated neurotransmission [114], implicated in weight regulation [115]. Thus, monitoring adverse effects of antipsychotics are important to alleviate behavioral symptoms without detrimental effects on metabolic health [116].

Selective serotonin reuptake inhibitors (SSRIs) are another class of medications commonly prescribed to children with ASD for comorbid anxiety, depression and obsessive-compulsive behaviors [117,118]. Previous research on the efficacy of citalopram [119] and fluoxetine [120] in children with ASD have not examined changes in weight gain. However, other research has suggested SSRIs such as citalopram may cause weight gain [121]. The degree and persistence of weight gain with these medications, particularly from long term use, are not known in children with ASD, and thus would benefit from further study.

\section{Emerging Factors}

\subsection{Breastfeeding}

Breast milk provides energy, nutrients and antibodies, and reduces risks for various infections during infancy [122]. Researchers have also studied how breastfeeding affects children's cognitive development. The rate and duration of exclusive breastfeeding also appears to be a potential risk 
factor for ASD [123]. For example, Boucher et al. found associations between longer durations of breastfeeding and better cognitive development and fewer autistic traits in children, after controlling for relevant demographic and social confounding variables [124]. Tseng et al. also reported that children with ASD were significantly less likely to have been breastfed than children without ASD [123]. Tseng et al. highlighted some proposed explanations for the role of breastfeeding in ASD pathophysiology, such as the nutrition theory [125], oxytocin stimulation [126], and the secretion of neurotrophic factors [123,127].

Researchers have also found that breastfeeding may lower the risk of childhood obesity [128,129]. In their meta-analysis, Yan et al. showed a dose-response effect between breastfeeding duration and reduced risk of childhood obesity [130]. These studies highlight that reduced breastfeeding may be a contributing factor to obesity, although they did not specifically examine these relationships in ASD. Thus, future studies could examine how breastfeeding affects the growth patterns and long-term weight status of children with ASD.

\subsection{Sleep}

Evidence suggests that sleep duration and quality of sleep are risk factors for becoming overweight or obese [131]. Numerous studies have confirmed an inverse correlation between sleep quantity, BMI, and the risk for overweight and obesity [132,133]. A 2016 meta-analysis found an association between poor sleep quality (independent of sleep duration) and overweight and obesity in children [134]. Decreased quality of sleep can lead to endocrine changes affecting appetite regulation and glucose metabolism, with implications on body weight gain [135]. As such, an inverse relationship between total sleep and ghrelin levels has been reported, as well as a positive relationship between total sleep and leptin levels [136]. Ghrelin and leptin are appetite regulating hormones that influence food intake. Childhood obesity can present with sleeping problems such as obstructive sleep apnea (OSA) [137]. OSA is associated with inadequate duration and poorer quality of sleep and may be associated with specific metabolic markers such as insulin resistance and hypertension [137].

Studies have found that children with ASD have higher rates of sleep problems when compared to TD controls [138]. One study found associations between poor sleep quality and weight status among children with ASD, with $86 \%$ of the obese group presenting with clinically significant sleep problems compared to $76 \%$ of those with healthy weight [139]. Children with ASD are more likely to be diagnosed with insomnia, circadian rhythm disorder, or sleep-disordered breathing such as OSA [140]. Metabolic risk factors, as well as day-time sleepiness, may reduce daytime activity levels, contributing to unhealthy weight gain [139]. Although many findings suggest that children with ASD are at greater risk for sleep problems, associations with BMI remain underexplored within this population. However, sleep duration and quality are important factors to consider, because increased findings of sleep problems may be compounding the risk for unhealthy weight gain in children with ASD.

\subsection{Microbiota}

Gastrointestinal (GI) disorders, such as diarrhea, chronic constipation [141], and abdominal pain are common in ASD [142]. In a study including 163 preschoolers with ASD, 25.8\% of the participants reported having at least one severe GI symptom [143]. Studies have also shown that children with ASD and GI problems have higher levels of affective problems, including anxiety, than children with ASD who have normal GI functioning $[14,143,144]$. This link between GI and behavior disorders suggests that gut microbiota may influence developmental course in ASD [145].

Data from several pediatric studies reveals a unique gut microbiota profile in children with ASD compared to those with TD, but inconsistent findings on the characterization of the bacterial communities [146]. While one study reported decreased bacteria of the genera Prevotella, Coprococcus and Veillonellaceae, other studies found increased Lactobacillus, Clostridium, Candida spp., and the Firmicutes/Bacteroidetes ratio [16,146-148]. Similar to what has been seen in ASD, studies exploring the gut microbiome in obesity have reported an increased Firmicutes/Bacteroidetes ratio, and this ratio 
could be positively associated with BMI in children and adults with obesity [149-151]. To further understand the implications of obesity on gut composition, animal studies comparing lean, wild-type, and obese mice (leptin-deficient) have demonstrated an increase in the Firmicutes/Bacteroidetes ratio in obese mice, independent of diet [152]. Indeed, a high-fat diet was shown to promote more profound increases in Firmicutes [153]. Certain features of the gut microbiota, such as individual variability, may explain the lack of a consistent microbiota signature in ASD and obesity. As the gut microbiota is assembled mainly during infancy, before the age of 2 years, diverse factors including birth mode, antibiotics, feeding practices, and environmental exposure to bacteria shape the gut community and contribute to this individual variability [154]. Thus, characterizing the microbiome from an ecological perspective (bacterial diversity, abundance, community interactions, metabolic profiles), may be more informative in understanding the interplay between gut microbiota, ASD prognosis, and weight gain.

Growing evidence suggests that decreased gut microbiota diversity in ASD [16,155] may be associated with behavioral and GI symptoms. Sharon et al. took this hypothesis a step forward, reporting that offspring of germ-free mice receiving gut microbiota from individuals with ASD indeed exhibited behaviors related to those observed in ASD [156]. This finding, however, must be interpreted with caution given the small sample size used in the experiments and relevance to behavioral expression in the human condition.

Gut microbiome dysbiosis, which refers to changes in the composition and function of gut microbiome especially early in life, are associated with increased production of pro-inflammatory cytokines and alterations in the dynamics of the communication between the gut and brain, known as the gut-brain axis [157-159]. These cytokines affect the inflammation pathways, which have been implicated in ASD development [158-160]. Inflammatory cytokines and an increased gut permeability also promote metabolic endotoxemia [161], which plays a role in the development of obesity and metabolic diseases [162]. Indeed, gut microbiome dysbiosis has also been reported in obesity [163].

A much-debated topic is whether gut permeability contributes to ASD development [159], with evidence remaining limited and controversial. To our knowledge, only three studies have investigated gut permeability in children with ASD using varied biomarkers [164-166]. Specifically, children with ASD exhibited greater gut permeability than TD children, as assessed by zonulin concentrations [164] or sugar probes (lactulose and mannitol) [165]. In contrast, no difference in gut permeability using the lactulose and rhamnose probe was observed in children with ASD compared to TD children [166]. There were marked differences in the design of these studies; in particular, with respect to the selection of comparison groups. One study included children with and without GI complaints in both study (i.e., children with ASD) and control (i.e., children with TD) groups; another study excluded children with GI symptoms from the control group only; and in the third study, all children (study and control groups) had mild GI disorders. Thus, it is not clear whether gut permeability is increased due to the presence of ASD or GI-associated disorders per se. Furthermore, studies have shown significantly lower short-chain fatty acids (SCFAs) in ASD [167]. As SCFAs are produced by gut microbiota (from dietary fiber fermentation), and their production promotes gut barrier and mucosal integrity [168], it could be speculated that individuals with ASD may have decreased ability to repair the intestinal barrier.

Dietary intake has a direct impact not only on obesity development, but also on the microbiome composition [169]; the role of diets in ASD could thereby be explored as a possible way to alleviate both irritable bowel syndrome symptoms and some ASD problem behaviors. An interesting avenue to explore would be fiber interventions in ASD, especially in those children with concomitant obesity. Many studies have found that fiber intake in children with ASD, as well as TD, does not meet recommended levels [8,42]. Fiber-rich foods can alleviate GI symptoms, such as chronic constipation and increase feelings of fullness, as these foods take longer to digest [170]. Fiber intake could also promote a healthier metabolic profile by mediating the gut microbiota [171,172]. Our bodies produce SCFAs by degrading fiber in the gut, which results in the release of anorexigenic gut hormones [173], improvements of the gut barrier [174], and triggering of anti-inflammatory cytokines [175,176]. More specifically, the SCFA propionate was shown to promote increases in peptide YY (PYY) and glucagon 
like peptide-1 (GLP-1) levels in an in vitro study using human colonic cells [177]. Subsequent in vivo studies were conducted in human adults; while acute intake of inulin-propionate ester reduced energy intake by $\approx 14 \%$ with increases in plasma PYY and GLP-1, supplementation over 24 weeks reduced rate of weight gain and intra-abdominal adiposity [177]. In addition to alleviating GI symptoms associated with ASD, SCFAs thus also prevented obesity and its comorbidities [178]. However, sensory aversions (e.g., to food texture) associated with ASD may create challenges with increasing intake of fiber rich foods.

Further delineating the microbial signature of individuals with comorbid ASD and obesity may provide further insight into the complex etiologies of both conditions. Although more studies are needed, there is emerging evidence of a dysbiotic gut microbiome influencing children with ASD. If supported by more definitive studies (e.g., metagenomics), evaluation of novel therapeutic strategies would be warranted, such as dietary interventions and fecal transplantations. Some challenges in this area include the need for approaches to directly sample the gut mucosa in order to reliably characterize the microbiome in various group and regions [179]. Furthermore, animal studies remain difficult to translate because of the precise control over genetics, the environment, and diet; which is not possible in human studies, making the human microbiome a lot more heterogeneous [179].

\subsection{Endocrine Influences}

Researchers have also begun to explore the role of endocrine factors in the pathogenesis of ASD. It has been hypothesized that specific chemical messengers, such as endocrine hormones, and neuropeptides work together with neurotransmitters (e.g., dopamine and serotonin) to influence the developing fetal brain [20]. Thus, imbalances in the chemical transmissions could lead to defective encoding, which could in turn lead to some of the social behaviors exhibited by those with ASD [20]. Research in this area has been focused on understanding how hormonal imbalances and differences may contribute to the pathogenesis of ASD. In this section, we review evidence related to specific appetite hormones, leptin, adiponectin and ghrelin.

\subsection{Leptin}

Leptin is an anorexigenic (satiety) hormone that regulates how much one consumes and inhibits appetite [180]. Produced by adipose tissue in amounts proportionate to fat mass [181], leptin is an important hormone involved in energy homeostasis and growth [182]. Evidence suggests that obese individuals exhibit leptin resistance, whereby the brain no longer responds to leptin by inhibiting energy intake and increasing energy expenditure [183,184].

Several studies have reported higher circulating concentrations of leptin in individuals with ASD compared to control groups $[18,19,185-188]$, summarized in Table 2. Ashwood et al. found higher concentrations of peripheral blood leptin in individuals with ASD compared to age-matched controls, despite no group differences in BMI [18]. Leptin plays an important role in growth [182] and rapid growth has also been independently implicated as a risk factor for ASD [189]. One study found that children born small-for-gestational age (SGA) had lower leptin cord levels; among those born SGA, children with the most rapid weight gain had the highest childhood leptin levels and were more likely to be diagnosed with ASD [187], suggesting differences in early weight trajectories between children with ASD and TD children [7]. Hasan et al. measured fasting serum concentrations for 20 children with ASD and 20 TD children; the BMI of the group with ASD was significantly lower compared to the control group; however, no children in either group were found to be of obese status [188]. The study found that the children with ASD had higher leptin concentrations and lower BMI [188], suggesting that leptin concentrations could be higher among individuals with ASD, regardless of weight status. The studies summarized in Table 2 have consistently found higher concentrations of leptin in children with ASD when compared to TD children. In the future, leptin concentrations could be analyzed based on BMI percentile stratifications to explore relationship to obesity among children with ASD. 
Table 2. Leptin in ASD.

\begin{tabular}{|c|c|c|c|c|c|c|}
\hline Study & Design & Study Group & Control Group & Measure & Result & BMI \\
\hline $\begin{array}{l}\text { Ashwood } \\
\text { et al. [18] }\end{array}$ & Case control & $\begin{array}{l}70 \text { male and female } \\
\text { children with ASD } \\
\text { (age: } 2-15 \text { years) }\end{array}$ & $\begin{array}{l}50 \text { age matched TD } \\
\text { children }\end{array}$ & $\begin{array}{l}\text { Peripheral plasma } \\
\text { concentrations of } \\
\text { leptin }\end{array}$ & $\begin{array}{l}\text { Leptin levels were higher in } \\
\text { children with autism compared } \\
\text { with typically developing } \\
\text { non-ASD controls }(p<0.006)\end{array}$ & $\begin{array}{l}\text { No statistical differences in } \\
\text { BMI or z-scores between } \\
\text { ASD or controls }\end{array}$ \\
\hline $\begin{array}{l}\text { Blardi et al. } \\
\text { [19] }\end{array}$ & Case control & $\begin{array}{l}35 \text { male and female } \\
\text { children with ASD } \\
\text { (mean age } 14.1 \text { years) }\end{array}$ & $\begin{array}{l}35 \mathrm{TD} \text { sex and age } \\
\text { matched children }\end{array}$ & $\begin{array}{l}\text { Baseline: } 6 \mathrm{~mL} \text { blood } \\
\text { sample after an } \\
\text { overnight fast } \\
1 \text { year after: } 6 \mathrm{~mL} \\
\text { blood sample after an } \\
\text { overnight fast }\end{array}$ & $\begin{array}{l}\text { Leptin concentrations of children } \\
\text { with ASD were significantly } \\
\text { higher than TD children at } \\
\text { baseline }(p<0.001) \text { and after a } \\
\text { year }(p<0.001)\end{array}$ & $\begin{array}{l}\text { No significant difference } \\
\text { between children with ASD } \\
\text { and TD children on weight or } \\
\text { height at baseline or after } 1 \\
\text { year } \\
\text { BMI z-score not provided }\end{array}$ \\
\hline $\begin{array}{l}\text { Al-Zaid et } \\
\text { al. [185] }\end{array}$ & Case control & $\begin{array}{l}31 \text { male children with } \\
\text { ASD } \\
\text { (age: } 3-8 \text { years) }\end{array}$ & $\begin{array}{l}28 \text { age- and } \\
\text { sex-matched TD } \\
\text { children (age: } 3-8 \\
\text { years) }\end{array}$ & $\begin{array}{l}7 \mathrm{~mL} \text { of venous blood } \\
\text { samples were } \\
\text { collected after an } \\
\text { overnight fast }\end{array}$ & $\begin{array}{l}\text { Leptin concentrations were } \\
\text { higher in the group with ASD } \\
\text { when compared to the TD group } \\
(p \leq 0.01)\end{array}$ & $\begin{array}{l}\text { Weight was higher in the } \\
\text { children with ASD }(19.3 \mathrm{~kg} \text { in } \\
\text { TD children and to } 22.7 \mathrm{~kg} \text { in } \\
\text { children with ASD) }(p=0.05) \\
\text { No significant difference in } \\
\text { BMI between groups ( } p= \\
0.28)\end{array}$ \\
\hline $\begin{array}{l}\text { Rodrigues } \\
\text { et al. [186] }\end{array}$ & Case control & $\begin{array}{l}30 \text { male and female } \\
\text { children with ASD } \\
\text { (ages not provided) }\end{array}$ & $\begin{array}{l}19 \text { TD children } \\
\text { matched for age, } \\
\text { gender, maternal age } \\
\text { at child birth }\end{array}$ & $\begin{array}{l}10 \mathrm{~mL} \text { plasma blood } \\
\text { samples }\end{array}$ & $\begin{array}{l}\text { Plasma levels of leptin were } \\
\text { higher }(p<0.01) \text { in children with } \\
\text { ASD, compared to TD children }\end{array}$ & $\begin{array}{l}\text { Article suggests differences } \\
\text { in BMI (unclear of } \\
\text { significance and values) }\end{array}$ \\
\hline $\begin{array}{l}\text { Raghavan } \\
\text { et al. [187] }\end{array}$ & Prospective cohort & $\begin{array}{l}39 \text { male and female } \\
\text { children with ASD }\end{array}$ & $\begin{array}{l}616 \text { male and female } \\
\text { TD children }\end{array}$ & $\begin{array}{l}\text { Plasma umbilical cord } \\
\text { blood sample and } \\
\text { non-fasting childhood } \\
\text { (median age }=18.4 \\
\text { months) venous } \\
\text { blood sample }\end{array}$ & $\begin{array}{l}\text { Mean cord leptin was lower in } \\
\text { children later diagnosed with } \\
\text { ASD }(p=0.05) \\
\text { Children with the highest leptin } \\
\text { levels had an increased ASD risk } \\
\text { (OR: } 5.41 ; 95 \% \text { CI: } 1.53,19.05)\end{array}$ & $\begin{array}{l}\text { Birthweight was greater in } \\
\text { TD children and compared to } \\
\text { children with ASD }(p=0.03) \\
\text { Extremely rapid weight gain } \\
\text { was associated with greater } \\
\text { ASD risk }\end{array}$ \\
\hline $\begin{array}{l}\text { Hasan et } \\
\text { al. [188] }\end{array}$ & Case control & $\begin{array}{l}20 \text { children with ASD } \\
\text { (16 males and } 4 \\
\text { females) } \\
\text { (mean age: } 5.9 \text { years) }\end{array}$ & $\begin{array}{l}20 \text { age matched TD } \\
\text { children ( } 13 \text { males } \\
\text { and } 7 \text { females) } \\
\text { (mean age: } 6.0 \text { years) }\end{array}$ & $\begin{array}{l}5 \mathrm{~mL} \text { blood samples } \\
\text { from participants } \\
\text { (serum) }\end{array}$ & $\begin{array}{l}\text { Serum levels of leptin were } \\
\text { higher in children with ASD } \\
\text { compared to TD children } \\
(p=0.038)\end{array}$ & $\begin{array}{l}\text { TD children had greater } \\
\text { mean weight }(p<0.001), \\
\text { height }(p<0.001) \text {, and BMI ( } p \\
<0.05) \text {, compared to children } \\
\text { with ASD }\end{array}$ \\
\hline
\end{tabular}

Abbreviations: ASD, Autism Spectrum Disorder; TD, Typically Developing; BMI, Body Mass Index 


\subsection{Adiponectin}

Adiponectin is a protein hormone secreted by the adipocytes [190]. Plasma adiponectin levels and BMI are strongly negatively correlated in both men and women [191]. Adiponectin is an anti-inflammatory protein [192]; decreased levels may lead to increased expression of adhesion molecules and inflammatory molecules, resulting in higher risk for cardiovascular diseases associated with obesity [193]. Therefore, adiponectin and its receptors may be therapeutic targets for individuals who are obese or overweight $[193,194]$.

Disturbances in immunoinflammatory factors and adipocytokines have been reported among individuals with ASD relative to age- and weight-matched TD controls [195]. Table 3 summarizes published data on adiponectin concentrations in children with ASD compared to controls $[19,186,196,197]$. One study reported lower serum adiponectin levels among individuals with ASD relative to age- and sex-matched healthy controls [196], but two other studies showed no significant differences $[19,186]$. Differences in findings among the three studies may be explained by differences in exclusion and inclusion criteria and sample composition, particularly by sex and age. For example, Rodrigues et al. and Blardi et al. included both males and females, whereas Fujita-Shimizu et al. only included males $[19,186,196]$. Past studies have found sex differences in adiponectin levels and body composition $[198,199]$, whereby adiponectin concentrations decrease into late puberty and become significantly lower in males by adulthood [199]. Furthermore, recent findings also suggest a link between a high leptin/adiponectin ratio (i.e., higher concentrations of leptin and lower concentrations of adiponectin) and abdominal obesity [200]. Although higher concentrations of leptin among individuals with ASD is a relatively consistent finding, the role of adiponectin is less clear. Exploring the relationship between these two hormones and its potential role in the propensity for individuals with ASD to become overweight or obese warrants further examination.

\subsection{Ghrelin}

Ghrelin is an appetite-stimulating hormone [201], but its exact role in obesity is poorly understood, as, counterintuitively, ghrelin is often suppressed in obese individuals, and concentrations increase with weight loss [202]. Evidence about the role of this hunger hormone in children with ASD is also unclear. Researchers have explored serum ghrelin concentrations in two case control studies of children with ASD (see Table 4). One study found that male children with ASD had significantly lower concentrations of acylated, des-acylated, and total ghrelin [185]. However, findings from a more recent study, that included both boys and girls, showed a trend towards lower concentrations of ghrelin, although not significant, in children with ASD when compared to age-matched TD children [188]. Previous studies have found that ghrelin levels can be modified by an increase in sex hormone [203], whereby testosterone can lead to marked decreases in ghrelin [203], which may contribute to differences in findings between these two studies. Future studies should examine ghrelin levels relative to weight status as well as ASD diagnosis and consider sex differences. 
Table 3. Adiponectin in ASD.

\begin{tabular}{|c|c|c|c|c|c|c|}
\hline Study & Design & Study Group & Control Group & Measure & Result & BMI \\
\hline $\begin{array}{l}\text { Blardi et al. } \\
\text { [19] }\end{array}$ & Case control & $\begin{array}{l}35 \text { male and female } \\
\text { children with ASD } \\
\text { (mean age } 14.1 \text { years) }\end{array}$ & $\begin{array}{l}35 \text { TD sex and age } \\
\text { matched children }\end{array}$ & $\begin{array}{l}\text { Baseline: } 6 \mathrm{~mL} \text { blood } \\
\text { sample after an } \\
\text { overnight fast } \\
1 \text { year after: } 6 \mathrm{~mL} \\
\text { blood sample after an } \\
\text { overnight }\end{array}$ & $\begin{array}{l}\text { Adiponectin levels in autistic } \\
\text { patients were not significantly } \\
\text { different from those found in } \\
\text { controls at each time. }\end{array}$ & $\begin{array}{l}\text { No significant difference } \\
\text { between children with ASD } \\
\text { and TD children on weight or } \\
\text { height at baseline or after } 1 \\
\text { year } \\
\text { BMI z-score not provided }\end{array}$ \\
\hline \multicolumn{2}{|c|}{$\begin{array}{l}\text { Fujita-ShimizuCase-control } \\
\text { et al. [196] }\end{array}$} & $\begin{array}{l}31 \text { male children with } \\
\text { ASD (age: 6-19 years) }\end{array}$ & $\begin{array}{l}31 \text { age-matched male } \\
\text { TD children (age: } \\
6-19 \text { years) }\end{array}$ & Fasting blood samples & $\begin{array}{l}\text { Serum levels of adiponectin in } \\
\text { the group with ASD were } \\
\text { significantly lower }(p=0.005) \\
\text { than the TD group }\end{array}$ & $\begin{array}{l}\text { No significant difference in } \\
\text { weight, height, waist } \\
\text { circumference, and BMI } \\
\text { between the two groups } \\
\text { BMI z-score or BMI weight } \\
\text { categories not provided }\end{array}$ \\
\hline $\begin{array}{l}\text { Rodrigues } \\
\text { et al. [186] }\end{array}$ & Case control & $\begin{array}{l}30 \text { male and female } \\
\text { children with ASD } \\
\text { (ages not provided) }\end{array}$ & $\begin{array}{l}19 \text { TD children } \\
\text { matched for age, } \\
\text { gender, maternal age } \\
\text { at child birth }\end{array}$ & $\begin{array}{l}10 \mathrm{~mL} \text { of blood } \\
\text { (plasma) }\end{array}$ & $\begin{array}{l}\text { No difference in the plasma } \\
\text { concentration of adiponectin in } \\
\text { children with ASD compared to } \\
\text { TD children }\end{array}$ & $\begin{array}{l}\text { Articles suggests differences } \\
\text { in BMI (unclear of } \\
\text { significance) } \\
\text { BMI z-score or BMI weight } \\
\text { categories not provided }\end{array}$ \\
\hline $\begin{array}{l}\text { Raghavan } \\
\text { et al. [197] }\end{array}$ & Prospective cohort & $\begin{array}{l}55 \text { male and female } \\
\text { children with ASD }\end{array}$ & $\begin{array}{l}792 \text { male and female } \\
\text { TD children }\end{array}$ & $\begin{array}{l}\text { Plasma umbilical cord } \\
\text { blood sample and } \\
\text { non-fasting childhood } \\
\text { (median age }=19.03 \\
\text { months) venous } \\
\text { blood sample }\end{array}$ & $\begin{array}{l}\text { Mean cord blood adiponectin } \\
\text { was higher in TD children } \\
\text { compared to the group with ASD } \\
(p=0.01) \\
\text { No significant difference in early } \\
\text { childhood adiponectin }\end{array}$ & $\begin{array}{l}\text { Birthweight was greater in } \\
\text { TD children and compared to } \\
\text { children with ASD }(p=0.03) \\
\text { Extremely rapid weight gain } \\
\text { was associated with greater } \\
\text { ASD risk }\end{array}$ \\
\hline
\end{tabular}

Abbreviations: ASD, Autism Spectrum Disorder; TD, Typically Developing; BMI, Body Mass Index. 
Table 4. Ghrelin in ASD.

\begin{tabular}{|c|c|c|c|c|c|c|}
\hline Study & Design & Study Group & Control Group & Measure & Result & BMI \\
\hline $\begin{array}{l}\text { Al-Zaid et } \\
\text { al. [185] }\end{array}$ & Case control & $\begin{array}{l}31 \text { male children with } \\
\text { ASD (age: 3-8 years) }\end{array}$ & $\begin{array}{l}28 \text { age- and } \\
\text { sex-matched TD } \\
\text { children (age: } 3-8 \\
\text { years) }\end{array}$ & $\begin{array}{l}7 \mathrm{~mL} \text { of venous blood } \\
\text { samples were } \\
\text { collected after an } \\
\text { overnight fast }\end{array}$ & $\begin{array}{l}\text { Acylated ghrelin concentrations } \\
\text { were lower in the group with } \\
\text { ASD than TD children }(p \leq 0.001) \\
\text { Deacylated ghrelin } \\
\text { concentrations were lower in } \\
\text { group with ASD compared to TD } \\
\text { children }(p \leq 0.005)\end{array}$ & $\begin{array}{l}\text { Weight was higher in the } \\
\text { children with ASD ( } 19.3 \mathrm{~kg} \text { in } \\
\text { TD children and to } 22.7 \mathrm{~kg} \text { in } \\
\text { children with ASD) ( } p=0.05) \\
\text { No significant difference in } \\
\text { BMI or height } \\
\text { BMI z-score or BMI weight } \\
\text { categories not provided }\end{array}$ \\
\hline $\begin{array}{l}\text { Hasan et } \\
\text { al. [188] }\end{array}$ & Case control & $\begin{array}{l}20 \text { male and female } \\
\text { children with ASD ( } 16 \\
\text { males and } 4 \text { females) } \\
\text { (mean age: } 5.9 \text { years) }\end{array}$ & $\begin{array}{l}20 \text { age-matched } \\
\text { healthy control } \\
\text { children ( } 13 \text { males } \\
\text { and } 7 \text { females) (mean } \\
\text { age: } 6.0 \text { years) }\end{array}$ & $\begin{array}{l}5 \mathrm{~mL} \text { blood samples } \\
\text { from participants } \\
\text { (serum) }\end{array}$ & $\begin{array}{l}\text { Serum levels of ghrelin were } \\
\text { lower in children with ASD } \\
\text { compared to TD children, but not } \\
\text { statistically significant }(p=0.32)\end{array}$ & $\begin{array}{l}\text { TD children had a greater } \\
\text { mean weight }(31.17 \mathrm{~kg}) \text {, } \\
\text { height }\left(1.32 \mathrm{~m}^{2}\right), \text { and BMI } \\
\left(17.6 \mathrm{~kg} / \mathrm{m}^{2}\right) \text { compared to } \\
\text { children with ASD with a } \\
\text { mean weight of } 21.26 \mathrm{~kg} \text {, } \\
\text { height of } 1.17 \mathrm{~m}^{2}, \text { and BMI of } \\
15.5 \mathrm{~kg} / \mathrm{m}^{2} \\
\text { BMI z-score or BMI weight } \\
\text { categories not provided }\end{array}$ \\
\hline
\end{tabular}

Abbreviations: ASD, Autism Spectrum Disorder; TD, Typically Developing; BMI, Body Mass Index. 
Although researchers have begun to explore the role of hormones in contributing to higher rates of obesity among children with ASD, they have focused primarily on hormonal differences in relation to ASD pathogenesis. Furthermore, some of the studies discussed above did not report a difference in BMI or weight status among children with ASD, when compared to TD children. However, the relatively smaller sample sizes, compared to larger scale studies (which have reported greater rates of obesity in children with ASD), may have contributed to these differences in findings [6,7]. Future studies, which stratify study groups based on weight status (overweight, obese, etc.), sex, and age would help to understand whether there are potential biological differences associated with specific weight status. Therefore, further research into possible differences in these hormones' concentrations, in children with ASD, may yield insights into hormonal impacts on unhealthy weight gain and obesity.

\subsection{Maternal Metabolic Disorders}

Although maternal metabolic disorders such as diabetes, hypertension and obesity could place children with ASD at higher risk for becoming overweight or obese, this hypothesis has not been explored directly. Instead, researchers have focused on examining maternal metabolic disorders as potential risk factors for ASD in children; separately, others have studied how maternal metabolic disorders may increase risk of obesity in children.

Maternal obesity prior to pregnancy is a risk factor for ASD [21,204,205]. Evidence has also shown significant associations between maternal diabetes and hypertension and ASD risk [206-208]. Several mechanisms may contribute to these in-utero effects. In a systematic review, Xu et al. suggested several potential pathways through which maternal diabetes may increase the risk for ASD in offspring: (a) maternal hyperglycemia can result in hypoxia and impair neural development in the fetus [209-211] (b) maternal hyperglycemia can cause oxidative stress associated with ASD risk [212,213], and (c) increased maternal adiposity can cause chronic inflammation that can affect neuronal development [206,214].

Concurrently, there has been considerable research on how maternal metabolic disorders may increase children's obesity risk. In their systematic review, Wang et al. found a strong positive association between parental and child obesity and overweight status across various countries, indicating a genetic predisposition toward obesity, with other factors playing a mediating role, such as obesogenic lifestyles and behaviors [22]. In another recent systematic review and meta-analysis, Kawasaki et al. reported an association between gestational diabetes mellitus and higher BMI z-scores among offspring [215]. Deierlein et al. found an association between fetal exposure to maternal glucose concentration in the high-normal range and children being overweight or obese at 3 years of age, independent of maternal pre-pregnancy BMI [216]. Furthermore, Lawlor et al. conducted a sibling analysis to control for shared genetics and environment and reported that children exposed to diabetes in utero had higher BMI than their unexposed siblings [217].

These findings may help explain how certain maternal metabolic disorders increase risk for obesity. Factors such as lifestyle behaviors and genetic predisposition may have compounded effects on weight gain for children with ASD. Additional research on in-utero effects of maternal metabolic disorders may help explain why many children with ASD tend to become overweight or obese. Longitudinal studies to assess parental weight status and track neurodevelopmental outcomes and weight in offspring would provide important insights into the extent to which parental obesity status influences the development of obesity in children with ASD. A better conceptualization of the role of maternal metabolic disorders and any shared pathophysiology between ASD and obesity would help mothers understand how to best reduce their children's risk for both health conditions.

\section{Future Directions and Perspectives}

The current treatments for childhood obesity generally involve a combination of (1) non-pharmacological interventions (e.g., behavioral treatments, weight-reducing diets), (2) pharmacological interventions, (3) and surgical treatments [23]. Typically, behavioral treatments and weight-reducing diets, such as family-based interventions, are the first therapeutic steps [218]. 
However, these may be problematic for children with ASD, who struggle with social and behavioral communication, changes in routine, and sensory processing difficulties [24,68]. Furthermore, challenges with self-management and, in many cases, impairments in decision-making skills play an important role in the challenges associated with this first line of treatment in children with ASD [219]. The second line of intervention is through common pharmacological treatments for childhood obesity, such as orlistat, sibutramine, and metformin. These, however, may cause abdominal pain, fecal incontinence, nausea, and vomiting [220,221]. Administering medications that can cause GI problems to children with ASD, who typically already have co-morbid GI disorders, may cause additional difficulties [222]. Moreover, because many children already take medication to manage symptoms of ASD and other comorbid medical conditions, additional medications may increase the risk of side effects, as well as pharmacological interactions and medication burden [223,224]. Finally, severe and morbid forms of pediatric obesity may warrant surgical interventions such as bariatric surgery [225]. Although the prevalence of severe morbid obesity (that would warrant consideration of bariatric surgery) among children with ASD is unclear, a study reported that children with the de novo 16p11.2 deletion, which is associated with autism, were also severely obese (BMI $\geq 120 \%$ of 95th percentile) [226]. Bariatric surgery, however, also comes with its risks and complications associated with Roux-en-Y gastric bypass, such as pulmonary embolism, shock, intestinal obstruction, postoperative bleeding, staple line leaks and severe malnutrition [23]. Furthermore, adolescents are more likely to have remission of type 2 diabetes and hypertension after bariatric surgery, when compared to adults [227], emphasizing that optimal timing for surgery in order to reverse metabolic complications of obesity is still unclear. Furthermore, little research has been done in this area to address treatment needs that may be specific to this population [219]. A systematic review looking more broadly at children with intellectual disabilities suggested the need for further research into how obesity treatment can be more specifically tailored for children with intellectual disabilities [219]. Finding more intensive treatments and combination of techniques are warranted for children with intellectual disabilities, such as more training for parents to support children with defiant behaviors [219,228].

Furthermore, although much is known about behavioral and lifestyle factors, little is known about possible biological drivers of obesity among children with ASD. There is also a need to identify whether specific biological drivers can be monitored and assessed at an earlier age, such as at the time of ASD diagnosis. Research in this area is particularly important, because evidence suggests that weight trajectories, at an earlier age, may be different among children with ASD. Therefore, clinical health surveillance of these weight trajectories in ASD and monitoring of growth patterns may serve as a useful method in preventing unhealthy weight gain and obesity. Based on this review, biological factors (gut microbiota, endocrine hormones, maternal metabolic disorders) may be driving increased propensity to become overweight, but further research is needed. Finally, given some of the unique challenges faced by children with ASD, results from pediatric obesity trials in the general population may not generalize to patients with ASD. Thus, as a field, we may require more targeted treatment options and ASD-specific randomized, controlled trials. In an era of precision medicine, there is a need to take into account the interplay between behavioral and biological characteristics influencing unhealthy weight gain in ASD.

\section{Conclusion and Recommendations}

Body weight is determined by energy balance, which is influenced by environmental (e.g., nutrition), behavioral (e.g., food selectivity, PA, SB), and biological (e.g., genetics, metabolic dysfunction) factors. Because the etiologies of ASD and obesity are so complex, risk factors specifically associated with one condition or the other are difficult to disentangle. Nevertheless, it is important to understand that many risk factors for becoming obese or overweight are heightened in individuals with ASD, as suggested by growing evidence. Figure 1 summarizes the risk factors discussed within this review. A limitation of this narrative review is that we compared various risk factors for unhealthy weight gain and obesity in children with ASD to TD children. Although similarities were found with regard to 
specific risk factors between children with ASD and TD children (i.e., physical activity, etc.), this does not necessarily mean these are not clinically relevant to children with ASD and should still be taken into account in future studies, including clinical trials.

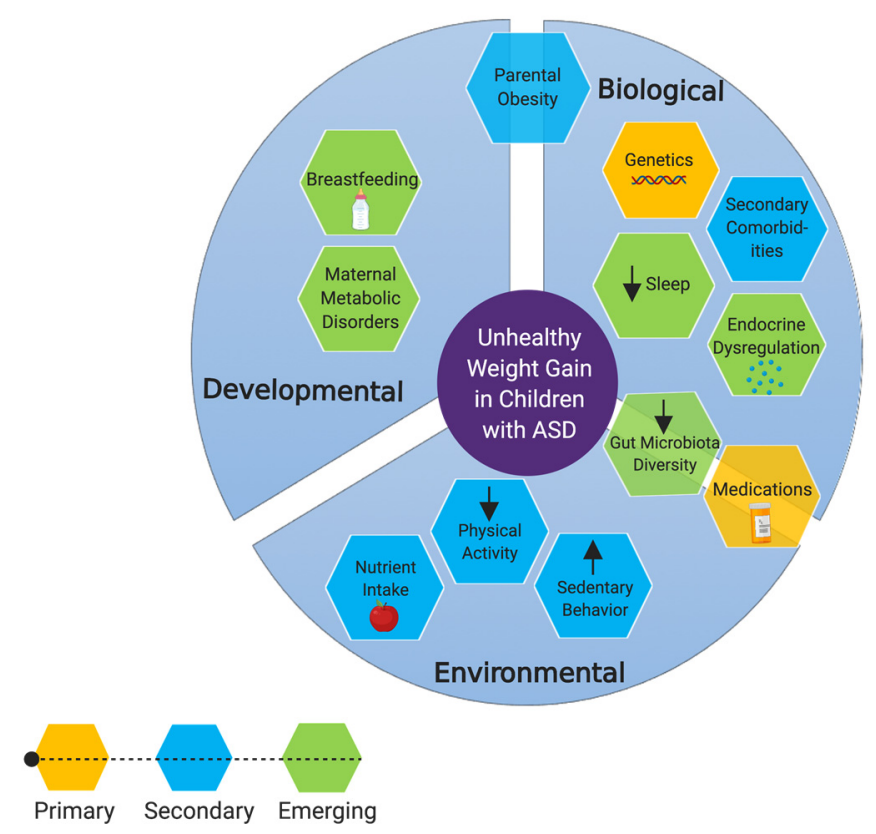

Figure 1. Risk factors for becoming obese or overweight among individuals with ASD. Primary factors include risk factors which have been directly implicated in obesity and/or unhealthy weight gain, in children with ASD. Secondary factors are those which are not specific to children with ASD but could result in unhealthy weight gain. Emerging factors are those on which we have postulated hypotheses based on indirect evidence. ${ }^{*}$ Created with BioRender.

Overall, evidence suggests that oral sensitivities may mediate food selectivity and food and nutrient intake and other factor such as PA, SB, sleep, genetics, and medication usage may all contribute to some degree, and ultimately have a compounded effect on weight gain in ASD. Additionally, researchers have begun to investigate the roles of sleep problems, the gut microbiome, the endocrine system, and developmental risk factors. Going forward, studies of obesity in ASD should incorporate assessment of both biological and lifestyle-related factors, as well as test for mediating and moderating relationships such as ASD severity, oral sensitivities, and sex and age differences. It is important to consider these multiple factors in conjunction with individual factors to clarify whether unhealthy weight gain affects children across the entire ASD spectrum, or whether certain children are more vulnerable than others. Understanding each of these individual risk factors and components is important to effectively prevent and treat unhealthy weight gain among children with ASD and to facilitate the development of potential early intervention strategies. An understanding of individual risk factors would enable the development of personalized approaches to help children with ASD manage their weight, including dietary recommendations, medical therapies, and nutrition and exercise regimens. Overall in conjunction with the clinical guidelines for pediatric obesity [229] and ASD care [98], clinicians should consider more tailored medical surveillance in children with ASD that considers the above factors in a care and management plan.

Author Contributions: K.K.D., A.M.H., and L.Z. devised the main conceptual ideas and outline of the review. K.K.D. wrote the review and conducted the literature search. C.E.O. contributed additional support in writing to specific subsections. C.E.O., A.M.H., and L.Z. provided their expertise and contributed to revising the article critically for important intellectual content and editing. C.R. provided her expertise in nutrition and contributions to revisions. All authors read and approved the final manuscript.

Acknowledgments: The authors express sincerely thanks to Autism Edmonton and the Autism Research Centre (at the Glenrose Rehabilitation Hospital in Edmonton, AB). This work was supported by the Autism Edmonton 
and Autism Research Centre Graduate Student Pilot Grant, the Glenrose Rehabilitation Hospital Foundation Clinical Research Grant, the Stollery Children's Hospital Foundation Chair in Autism, and the Alberta Diabetes Institute. C.E.O is a recipient of the 2018 Alberta SPOR Graduate Studentship in Patient-Oriented Research, which is jointly funded by Alberta Innovates and the Canadian Institutes of Health Research. L.Z is supported by the Stollery Children's Hospital Foundation in Autism and the Stollery Science Lab.

Conflicts of Interest: The authors declare no conflicts of interest.

$\begin{array}{ll}\text { Abbreviations } \\ \text { ADHD } & \text { Attention Deficit Hyperactivity Disorder } \\ \text { AMDR } & \text { Acceptable Macronutrient Distribution Range } \\ \text { ASD } & \text { Autism Spectrum Disorder } \\ \text { BMI } & \text { Body Mass Index } \\ \text { BPFA } & \text { Behavior Pediatrics Feeding Assessment Scale } \\ \text { FFQ } & \text { Food Frequency Questionnaire } \\ \text { GFCF } & \text { Gluten-Free Casein-Free } \\ \text { GI } & \text { Gastrointestinal } \\ \text { GLP-1 } & \text { Glucagon-Like Peptide- 1 } \\ \text { MVPA } & \text { Moderate- to Vigorous-intensity Physical Activity } \\ \text { OSA } & \text { Obstructive Sleep Apnea } \\ \text { PA } & \text { Physical Activity } \\ \text { PYY } & \text { Peptide YY } \\ \text { PWS } & \text { Prader-Willi Syndrome } \\ \text { RCT } & \text { Randomized Controlled Trial } \\ \text { SB } & \text { Sedentary Behavior } \\ \text { SCFA } & \text { Short-Chain Fatty Acid } \\ \text { SGA } & \text { Second Generation Antipsychotic } \\ \text { SSRI } & \text { Selective Serotonin Reuptake Inhibitors } \\ \text { TD } & \text { Typically Developing } \\ \end{array}$

\section{References}

1. Lai, M.-C.; Lombardo, M.V.; Baron-Cohen, S. Autism. Lancet 2014, 383, 896-910. [CrossRef]

2. American Psychiatric Association. Diagnostic and Statistical Manual of Mental Disorders (DSM-5), 5th ed.; American Psychiatric Association: Arlington, VA, USA, 2013.

3. World Health Organization. Autism spectrum disorders. Available online: https://www.who.int/news-room/ fact-sheets/detail/autism-spectrum-disorders (accessed on 26 May 2019).

4. Baio, J.; Wiggins, L.; Christensen, D.L.; Maenner, M.J.; Daniels, J.; Warren, Z.; Kurzius-Spencer, M. Prevalence of Autism Spectrum Disorder Among Children Aged 8 Years-Autism and Developmental Disabilities Monitoring Network, 11 Sites, United States, 2014. MMWR Surveill. Summ. 2018, 67, 1-23. [CrossRef] [PubMed]

5. Ofner, M.; Coles, A.; Decou, M.L.; Do, M.T.; Bienek, A.; Snider, J.; Ugnat, A.-M. Autism spectrum disorder among children and youth in Canada 2018: A report of the National Autism Spectrum Disorder Surveillance System. Available online: https://www.canada.ca/en/public-health/services/publications/diseases-conditions/ autism-spectrum-disorder-children-youth-canada-2018.html (accessed on 5 May 2019).

6. Zheng, Z.; Zhang, L.; Li, S.; Zhao, F.; Wang, Y.; Huang, L.; Huang, J.; Zou, R.; Qu, Y.; Mu, D. Association among obesity, overweight and autism spectrum disorder: A systematic review and meta-analysis. Sci. Rep. 2017, 7, 11697. [CrossRef] [PubMed]

7. Hill, A.P.; Zuckerman, K.E.; Fombonne, E. Obesity and Autism. Pediatrics 2015, 136, 1051-1061. [CrossRef]

8. Hyman, S.L.; Stewart, P.A.; Schmidt, B.; Cain, U.; Lemcke, N.; Foley, J.T.; Peck, R.; Clemons, T.; Reynolds, A.; Johnson, C.; et al. Nutrient intake from food in children with autism. Pediatrics 2012, 130, S145-S153. [CrossRef] [PubMed]

9. Steinberger, J.; Daniels, S.R. Obesity, insulin resistance, diabetes, and cardiovascular risk in children. Circulation 2003, 107, 1448-1453. [CrossRef] [PubMed] 
10. Weihrauch-Blüher, S.; Schwarz, P.; Klusmann, J.-H. Childhood obesity: Increased risk for cardiometabolic disease and cancer in adulthood. Metab. Clin. Exp. 2019, 92, 147-152. [CrossRef]

11. Khodaverdi, F.; Alhani, F.; Kazemnejad, A.; Khodaverdi, Z. The Relationship between Obesity and Quality of Life in School Children. Iran. J. Public Health 2011, 40, 96-101.

12. Bandini, L.; Curtin, C.; Phillips, S.; Anderson, S.E.; Maslin, M.; Must, A. Changes in food selectivity in children with autism spectrum disorder. J. Autism Dev. Disord. 2017, 47, 439-446. [CrossRef]

13. Askari, S.; Anaby, D.; Bergthorson, M.; Majnemer, A.; Elsabbagh, M.; Zwaigenbaum, L. Participation of Children and Youth with Autism Spectrum Disorder: A Scoping Review. Rev. J. Autism Dev. Disord. 2015, 2, 103-114. [CrossRef]

14. Ferguson, B.J.; Marler, S.; Altstein, L.L.; Lee, E.B.; Akers, J.; Sohl, K.; McLaughlin, A.; Hartnett, K.; Kille, B.; Mazurek, M.; et al. Psychophysiological Associations with Gastrointestinal Symptomatology in Autism Spectrum Disorder. Autism Res. 2017, 10, 276-288. [CrossRef] [PubMed]

15. Maneeton, N.; Maneeton, B.; Puthisri, S.; Woottiluk, P.; Narkpongphun, A.; Srisurapanont, M. Risperidone for children and adolescents with autism spectrum disorder: A systematic review. Available online: https://www.dovepress.com/risperidone-for-children-and-adolescents-with-autismspectrum-disorder-peer-reviewed-fulltext-article-NDT (accessed on 20 May 2019).

16. Kang, D.-W.; Park, J.G.; Ilhan, Z.E.; Wallstrom, G.; Labaer, J.; Adams, J.B.; Krajmalnik-Brown, R. Reduced incidence of Prevotella and other fermenters in intestinal microflora of autistic children. PLoS ONE 2013, 8, e68322. [CrossRef] [PubMed]

17. Castaner, O.; Goday, A.; Park, Y.-M.; Lee, S.-H.; Magkos, F.; Shiow, S.-A.T.E.; Schröder, H. The Gut Microbiome Profile in Obesity: A Systematic Review. Int. J. Endocrinol. 2018, 1-9. [CrossRef] [PubMed]

18. Ashwood, P.; Kwong, C.; Hansen, R.; Hertz-Picciotto, I.; Croen, L.; Krakowiak, P.; Walker, W.; Pessah, I.N.; Van de Water, J. Brief report: Plasma leptin levels are elevated in autism: Association with early onset phenotype? J. Autism Dev. Disord. 2008, 38, 169-175. [CrossRef] [PubMed]

19. Blardi, P.; de Lalla, A.; Ceccatelli, L.; Vanessa, G.; Auteri, A.; Hayek, J. Variations of plasma leptin and adiponectin levels in autistic patients. Neurosci. Lett. 2010, 479, 54-57. [CrossRef] [PubMed]

20. Tareen, R.S.; Kamboj, M.K. Role of endocrine factors in autistic spectrum disorders. Pediatr. Clin. N. Am. 2012, 59, 75-88. [CrossRef] [PubMed]

21. Reynolds, L.C.; Inder, T.E.; Neil, J.J.; Pineda, R.G.; Rogers, C.E. Maternal obesity and increased risk for autism and developmental delay among very preterm infants. J. Perinatol. 2014, 34, 688-692. [CrossRef]

22. Wang, Y.; Min, J.; Khuri, J.; Li, M. A Systematic Examination of the Association between Parental and Child Obesity across Countries123. Adv. Nutr. 2017, 8, 436-448. [CrossRef]

23. Han, J.C.; Lawlor, D.A.; Kimm, S.Y.S. Childhood Obesity-2010: Progress and Challenges. Lancet 2010, 375, 1737-1748. [CrossRef]

24. Leekam, S.R.; Nieto, C.; Libby, S.J.; Wing, L.; Gould, J. Describing the Sensory Abnormalities of Children and Adults with Autism. J. Autism Dev. Disord. 2007, 37, 894-910. [CrossRef]

25. Kern, J.K.; Trivedi, M.H.; Garver, C.R.; Grannemann, B.D.; Andrews, A.A.; Savla, J.S.; Johnson, D.G.; Mehta, J.A.; Schroeder, J.L. The pattern of sensory processing abnormalities in autism. Autism 2006, 10, 480-494. [CrossRef] [PubMed]

26. Cermak, S.A.; Curtin, C.; Bandini, L.G. Food selectivity and sensory sensitivity in children with autism spectrum disorders. J. Am. Diet. Assoc. 2010, 110, 238-246. [CrossRef] [PubMed]

27. Sharp, W.G.; Berry, R.C.; McCracken, C.; Nuhu, N.N.; Marvel, E.; Saulnier, C.A.; Klin, A.; Jones, W.; Jaquess, D.L. Feeding Problems and Nutrient Intake in Children with Autism Spectrum Disorders: A Meta-analysis and Comprehensive Review of the Literature. J. Autism Dev. Disord. 2013, 43, 2159-2173. [CrossRef] [PubMed]

28. Shmaya, Y.; Eilat-Adar, S.; Leitner, Y.; Reif, S.; Gabis, L. Nutritional deficiencies and overweight prevalence among children with autism spectrum disorder. Res. Dev. Disabil. 2015, 38, 1-6. [CrossRef] [PubMed]

29. Castro, K.; Faccioli, L.S.; Baronio, D.; Gottfried, C.; Perry, I.S.; Riesgo, R. Feeding behavior and dietary intake of male children and adolescents with autism spectrum disorder: A case-control study. Int. J. Dev. Neurosci. 2016, 53, 68-74. [CrossRef] [PubMed]

30. Liu, X.; Liu, J.; Xiong, X.; Yang, T.; Hou, N.; Liang, X.; Chen, J.; Cheng, Q.; Li, T. Correlation between Nutrition and Symptoms: Nutritional Survey of Children with Autism Spectrum Disorder in Chongqing, China. Nutrients 2016, 8, 294. [CrossRef] [PubMed] 
31. Evans, E.W.; Must, A.; Anderson, S.E.; Curtin, C.; Scampini, R.; Maslin, M.; Bandini, L. Dietary Patterns and Body Mass Index in Children with Autism and Typically Developing Children. Res. Autism Spectr. Disord. 2012, 6, 399-405. [CrossRef]

32. Chao, H.-C. Association of Picky Eating with Growth, Nutritional Status, Development, Physical Activity, and Health in Preschool Children. Front. Pediatr. 2018, 6, 22. [CrossRef]

33. Esteban-Figuerola, P.; Canals, J.; Fernández-Cao, J.C.; Arija Val, V. Differences in food consumption and nutritional intake between children with autism spectrum disorders and typically developing children: A meta-analysis. Autism 2018, 23, 1079-1095. [CrossRef]

34. Wan, Y.; Wang, F.; Yuan, J.; Li, J.; Jiang, D.; Zhang, J.; Huang, T.; Zheng, J.; Mann, J.; Li, D. Effects of Macronutrient Distribution on Weight and Related Cardiometabolic Profile in Healthy Non-Obese Chinese: A 6-month, Randomized Controlled-Feeding Trial. EBioMedicine 2017, 22, 200-207. [CrossRef]

35. Hjorth, M.F.; Ritz, C.; Blaak, E.E.; Saris, W.H.; Langin, D.; Poulsen, S.K.; Larsen, T.M.; Sørensen, T.I.; Zohar, Y.; Astrup, A. Pretreatment fasting plasma glucose and insulin modify dietary weight loss success: Results from 3 randomized clinical trials. Am. J. Clin. Nutr. 2017, 106, 499-505. [CrossRef] [PubMed]

36. Gow, M.L.; Ho, M.; Burrows, T.L.; Baur, L.A.; Stewart, L.; Hutchesson, M.J.; Cowell, C.T.; Collins, C.E.; Garnett, S.P. Impact of dietary macronutrient distribution on BMI and cardiometabolic outcomes in overweight and obese children and adolescents: A systematic review. Nutr. Rev. 2014, 72, 453-470. [CrossRef] [PubMed]

37. Via, M. The Malnutrition of Obesity: Micronutrient Deficiencies That Promote Diabetes. ISRN Endocrinol. 2012, 2012, 103472. [CrossRef] [PubMed]

38. Hyman, S.L.; Stewart, P.A.; Foley, J.; Cain, U.; Peck, R.; Morris, D.D.; Wang, H.; Smith, T. The gluten-free/casein-free diet: A double-blind challenge trial in children with autism. J. Autism Dev. Disord. 2016, 46, 205-220. [CrossRef] [PubMed]

39. Sathe, N.; Andrews, J.C.; McPheeters, M.L.; Warren, Z.E. Nutritional and dietary interventions for autism spectrum disorder: A systematic review. Pediatrics 2017, 139, e20170346. [CrossRef] [PubMed]

40. Herndon, A.C.; DiGuiseppi, C.; Johnson, S.L.; Leiferman, J.; Reynolds, A. Does nutritional intake differ between children with autism spectrum disorders and children with typical development? J. Autism Dev. Disord. 2009, 39, 212-222. [CrossRef]

41. Zimmer, M.H.; Hart, L.C.; Manning-Courtney, P.; Murray, D.S.; Bing, N.M.; Summer, S. Food variety as a predictor of nutritional status among children with autism. J. Autism Dev. Disord. 2012, 42, 549-556. [CrossRef] [PubMed]

42. Bandini, L.G.; Anderson, S.E.; Curtin, C.; Cermak, S.; Evans, E.W.; Scampini, R.; Maslin, M.; Must, A. Food selectivity in children with autism spectrum disorders and typically developing children. J. Pediatr. 2010, 157, 259-264. [CrossRef]

43. García, O.P.; Long, K.Z.; Rosado, J.L. Impact of micronutrient deficiencies on obesity. Nutr. Rev. 2009, 67, 559-572. [CrossRef]

44. Yu, Z.M.; DeClercq, V.; Cui, Y.; Forbes, C.; Grandy, S.; Keats, M.; Parker, L.; Sweeney, E.; Dummer, T.J.B. Fruit and vegetable intake and body adiposity among populations in Eastern Canada: The Atlantic Partnership for Tomorrow's Health study. BMJ Open 2018, 8, e018060. [CrossRef]

45. Bertoia, M.L.; Mukamal, K.J.; Cahill, L.E.; Hou, T.; Ludwig, D.S.; Mozaffarian, D.; Willett, W.C.; Hu, F.B.; Rimm, E.B. Changes in intake of fruits and vegetables and weight change in united states men and women followed for up to 24 years: Analysis from three prospective cohort studies. PLoS Med. 2015, 12, e1001878. [CrossRef] [PubMed]

46. Graf-Myles, J.; Farmer, C.; Thurm, A.; Royster, C.; Kahn, P.; Soskey, L.; Rothschild, L.; Swedo, S. Dietary adequacy of children with autism compared to controls and the impact of restricted diet. J. Dev. Behav. Pediatr. 2013, 34, 449-459. [CrossRef] [PubMed]

47. Riccio, M.P.; Franco, C.; Negri, R.; Ferrentino, R.I.; Maresca, R.; D’alterio, E.; Greco, L.; Bravaccio, C. Is food refusal in autistic children related to TAS2R38 genotype? Autism Res. 2018, 11, 531-538. [CrossRef] [PubMed]

48. Joseph, P.V.; Reed, D.R.; Mennella, J.A. Individual Differences Among Children in Sucrose Detection Thresholds: Relationship with Age, Gender, and Bitter Taste Genotype. Nurs. Res. 2016, 65, 3-12. [CrossRef] [PubMed]

49. Mennella, J.A.; Bobowski, N.K. The sweetness and bitterness of childhood: Insights from basic research on taste preferences. Physiol. Behav. 2015, 152, 502-507. [CrossRef] [PubMed] 
50. Yang, Y.J.; Kim, M.K.; Hwang, S.H.; Ahn, Y.; Shim, J.E.; Kim, D.H. Relative validities of 3-day food records and the food frequency questionnaire. Nutr. Res. Pract. 2010, 4, 142-148. [CrossRef]

51. Macdiarmid, J.; Blundell, J. Assessing dietary intake: Who, what and why of under-reporting. Nutr. Res. Rev. 1998, 11, 231-253. [CrossRef]

52. Subar, A.F.; Freedman, L.S.; Tooze, J.A.; Kirkpatrick, S.I.; Boushey, C.; Neuhouser, M.L.; Thompson, F.E.; Potischman, N.; Guenther, P.M.; Tarasuk, V.; et al. Addressing current criticism regarding the value of self-report dietary data. J. Nutr. 2015, 145, 2639-2645. [CrossRef]

53. Naska, A.; Lagiou, A.; Lagiou, P. Dietary assessment methods in epidemiological research: Current state of the art and future prospects. F1000 Res. 2017, 6, 926. [CrossRef]

54. Westerterp, K.R. Doubly labelled water assessment of energy expenditure: Principle, practice, and promise. Eur. J. Appl. Physiol. 2017, 117, 1277-1285. [CrossRef]

55. Dudova, I.; Kocourkova, J.; Koutek, J. Early-onset anorexia nervosa in girls with Asperger syndrome. Neuropsychiatr. Dis. Treat. 2015, 11, 1639-1643. [CrossRef] [PubMed]

56. Baron-Cohen, S.; Jaffa, T.; Davies, S.; Auyeung, B.; Allison, C.; Wheelwright, S. Do girls with anorexia nervosa have elevated autistic traits? Mol. Autism 2013, 4, 24. [CrossRef] [PubMed]

57. Kirkovski, M.; Enticott, P.G.; Fitzgerald, P.B. A Review of the Role of Female Gender in Autism Spectrum Disorders. J. Autism Dev. Disord. 2013, 43, 2584-2603. [CrossRef] [PubMed]

58. Goran, M.I.; Reynolds, K.D.; Lindquist, C.H. Role of physical activity in the prevention of obesity in children. Int. J. Obes. 1999, 23, S18-S33. [CrossRef]

59. Andari, E.; Duhamel, J.-R.; Zalla, T.; Herbrecht, E.; Leboyer, M.; Sirigu, A. Promoting social behavior with oxytocin in high-functioning autism spectrum disorders. Proc. Natl. Acad. Sci. USA 2010, 107, 4389-4394. [CrossRef] [PubMed]

60. Bishop, S.L.; Havdahl, K.A.; Huerta, M.; Lord, C. Sub-dimensions of social-communication impairment in autism spectrum disorder. J. Child Psychol. Psychiatry 2016, 57, 909-916. [CrossRef] [PubMed]

61. National Institute of Mental Health. Autism Spectrum Disorder. Available online: https://www.nimh.nih. gov/health/topics/autism-spectrum-disorders-asd/index.shtml (accessed on 6 May 2019).

62. McPhillips, M.; Finlay, J.; Bejerot, S.; Hanley, M. Motor deficits in children with autism spectrum disorder: A cross-syndrome study. Autism Res. 2014, 7, 664-676. [CrossRef]

63. Serdarevic, F.; Ghassabian, A.; van Batenburg-Eddes, T.; White, T.; Blanken, L.M.E.; Jaddoe, V.W.V.; Verhulst, F.C.; Tiemeier, H. Infant muscle tone and childhood autistic traits: A longitudinal study in the general population. Autism Res. 2017, 10, 757-768. [CrossRef]

64. World Health Organization. Physical Activity and Young People. Available online: https://www.who.int/ dietphysicalactivity/factsheet_young_people/en/(accessed on 2 May 2019).

65. U.S. Department of Health and Human Services. Current Guidelines. Available online: https://health.gov/ paguidelines/second-edition/ (accessed on 28 May 2019).

66. Bandini, L.G.; Gleason, J.; Curtin, C.; Lividini, K.; Anderson, S.E.; Cermak, S.A.; Maslin, M.; Must, A. Comparison of physical activity between children with autism spectrum disorders and typically developing children. Autism 2013, 17, 44-54. [CrossRef]

67. Stanish, H.I.; Curtin, C.; Must, A.; Phillips, S.; Maslin, M.; Bandini, L.G. Physical activity levels, frequency, and type among adolescents with and without autism spectrum disorder. J. Autism Dev. Disord. 2017, 47, 785-794. [CrossRef]

68. Jones, R.A.; Downing, K.; Rinehart, N.J.; Barnett, L.M.; May, T.; McGillivray, J.A.; Papadopoulos, N.V.; Skouteris, H.; Timperio, A.; Hinkley, T. Physical activity, sedentary behavior and their correlates in children with Autism Spectrum Disorder: A systematic review. PLoS ONE 2017, 12, e0172482. [CrossRef]

69. Griffiths, L.J.; Cortina-Borja, M.; Sera, F.; Pouliou, T.; Geraci, M.; Rich, C.; Cole, T.J.; Law, C.; Joshi, H.; Ness, A.R.; et al. How active are our children? Findings from the Millennium Cohort Study. BMJ Open 2013, 3, e002893. [CrossRef] [PubMed]

70. Must, A.; Phillips, S.; Curtin, C.; Bandini, L.G. Barriers to physical activity in children with autism spectrum disorders: Relationship to physical activity and screen time. J. Phys. Act. Health 2015, 12, 529-534. [CrossRef] [PubMed]

71. McCoy, S.M.; Jakicic, J.M.; Gibbs, B.B. Comparison of obesity, physical activity, and sedentary behaviors between adolescents with autism spectrum disorders and without. J. Autism Dev. Disord. 2016, 46, 2317-2326. [CrossRef] 
72. Healy, S.; Haegele, J.A.; Grenier, M.A.; Garcia, J.M. Physical activity, screen-time behavior, and obesity among 13-year-olds in Ireland with and without autism spectrum disorder. J. Autism Dev. Disord. 2017, 47, 49-57. [CrossRef] [PubMed]

73. Sarker, H.; Anderson, L.N.; Borkhoff, C.M.; Abreo, K.; Tremblay, M.S.; Lebovic, G.; Maguire, J.L.; Parkin, P.C.; Birken, C.S. Validation of parent-reported physical activity and sedentary time by accelerometry in young children. BMC Res. Notes 2015, 8, 1-8. [CrossRef]

74. Dössegger, A.; Ruch, N.; Jimmy, G.; Braun-Fahrländer, C.; Mäder, U.; Hänggi, J.; Hofmann, H.; Puder, J.J.; Kriemler, S.; Bringolf-Isler, B. Reactivity to accelerometer measurement of children and adolescents. Med. Sci. Sports Exerc. 2014, 46, 1140-1146. [CrossRef]

75. Koning, M.; de Jong, A.; de Jong, E.; Visscher, T.L.S.; Seidell, J.C.; Renders, C.M. Agreement between parent and child report of physical activity, sedentary and dietary behaviours in 9-12-year-old children and associations with children's weight status. BMC Psychol. 2018, 6, 14. [CrossRef] [PubMed]

76. Owen, N.; Sparling, P.B.; Healy, G.N.; Dunstan, D.W.; Matthews, C.E. Sedentary behavior: Emerging evidence for a new health risk. Mayo Clin. Proc. 2010, 85, 1138-1141. [CrossRef]

77. Matthews, C.E.; Chen, K.Y.; Freedson, P.S.; Buchowski, M.S.; Beech, B.M.; Pate, R.R.; Troiano, R.P. Amount of time spent in sedentary behaviors in the United States, 2003-2004. Am. J. Epidemiol. 2008, 167, 875-881. [CrossRef]

78. Dunton, G.F.; Liao, Y.; Intille, S.S.; Spruijt-Metz, D.; Pentz, M. Investigating children's physical activity and sedentary behavior using ecological momentary assessment with mobile phones. Obesity 2011, 19, 1205-1212. [CrossRef] [PubMed]

79. Biswas, A.; Oh, P.I.; Faulkner, G.E.; Bajaj, R.R.; Silver, M.A.; Mitchell, M.S.; Alter, D.A. Sedentary time and its association with risk for disease incidence, mortality, and hospitalization in adults: A systematic review and meta-analysis. Ann. Intern. Med. 2015, 162, 123. [CrossRef] [PubMed]

80. Ekelund, U.; Brage, S.; Besson, H.; Sharp, S.; Wareham, N.J. Time spent being sedentary and weight gain in healthy adults: Reverse or bidirectional causality? Am. J. Clin. Nutr. 2008, 88, 612-617. [CrossRef] [PubMed]

81. Mazurek, M.O.; Wenstrup, C. Television, video game and social media use among children with ASD and typically developing siblings. J. Autism Dev. Disord. 2013, 43, 1258-1271. [CrossRef] [PubMed]

82. Mazurek, M.O.; Shattuck, P.T.; Wagner, M.; Cooper, B.P. Prevalence and correlates of screen-based media use among youths with autism spectrum disorders. J. Autism Dev. Disord. 2012, 42, 1757-1767. [CrossRef] [PubMed]

83. MacDonald, M.; Lord, C.; Ulrich, D.A. Motor skills and calibrated autism severity in young children with autism spectrum disorder. Adapt. Phys. Activ. Q 2014, 31, 95-105. [CrossRef] [PubMed]

84. Constantino, J.N.; Zhang, Y.; Frazier, T.; Abbacchi, A.M.; Law, P. Sibling recurrence and the genetic epidemiology of autism. Am. J. Psychiatry 2010, 167, 1349-1356. [CrossRef]

85. Sandin, S.; Lichtenstein, P.; Kuja-Halkola, R.; Hultman, C.; Larsson, H.; Reichenberg, A. The heritability of autism spectrum disorder. JAMA 2017, 318, 1182-1184. [CrossRef]

86. Chesi, A.; Grant, S.F.A. The genetics of pediatric obesity. Trends Endocrinol. Metab. 2015, 26, 711-721. [CrossRef]

87. Sørensen, T.I.; Stunkard, A.J. Does obesity run in families because of genes? An adoption study using silhouettes as a measure of obesity. Acta Psychiatr. Scand. Suppl. 1993, 370, 67-72. [CrossRef]

88. Sharma, J.R.; Arieff, Z.; Sagar, S.; Kaur, M. Autism and obesity: Prevalence, molecular basis and potential therapies. Autism Insights 2012, 4, 1-13.

89. Shinawi, M.; Sahoo, T.; Maranda, B.; Skinner, S.A.; Skinner, C.; Chinault, C.; Zascavage, R.; Peters, S.U.; Patel, A.; Stevenson, R.E.; et al. 11p14.1 microdeletions associated with ADHD, autism, developmental delay, and obesity. Am. J. Med. Genet. A 2011, 155A, 1272-1280. [CrossRef] [PubMed]

90. Walters, R.G.; Jacquemont, S.; Valsesia, A.; de Smith, A.J.; Martinet, D.; Andersson, J.; Falchi, M.; Chen, F.; Andrieux, J.; Lobbens, S.; et al. A new highly penetrant form of obesity due to deletions on chromosome 16p11.2. Nature 2010, 463, 671-675. [CrossRef] [PubMed]

91. Bachmann-Gagescu, R.; Mefford, H.C.; Cowan, C.; Glew, G.M.; Hing, A.V.; Wallace, S.; Bader, P.I.; Hamati, A.; Reitnauer, P.J.; Smith, R.; et al. Recurrent 200-kb deletions of 16p11.2 that include the SH2B1 gene are associated with developmental delay and obesity. Genet. Med. 2010, 12, 641-647. [CrossRef] [PubMed]

92. Cortes, H.D.; Wevrick, R. Genetic analysis of very obese children with autism spectrum disorder. Mol. Genet. Genom. 2018, 293, 725-736. [CrossRef] [PubMed] 
93. Dykens, E.M.; Lee, E.; Roof, E. Prader-Willi syndrome and autism spectrum disorders: An evolving story. J. Neurodev. Disord. 2011, 3, 225-237. [CrossRef] [PubMed]

94. Haqq, A.M.; Grambow, S.C.; Muehlbauer, M.; Newgard, C.B.; Svetkey, L.P.; Carrel, A.L.; Yanovski, J.A.; Purnell, J.Q.; Freemark, M. Ghrelin concentrations in Prader-Willi syndrome (PWS) infants and children. Clin. Endocrinol. (Oxf.) 2008, 69, 911-920. [CrossRef] [PubMed]

95. Bennett, J.A.; Hodgetts, S.; Mackenzie, M.L.; Haqq, A.M.; Zwaigenbaum, L. Investigating Autism-Related Symptoms in Children with Prader-Willi Syndrome: A Case Study. Int. J. Mol. Sci. 2017, 18, 517. [CrossRef] [PubMed]

96. Dykens, E.M.; Roof, E.; Hunt-Hawkins, H.; Dankner, N.; Lee, E.B.; Shivers, C.M.; Daniell, C.; Kim, S.-J. Diagnoses and characteristics of autism spectrum disorders in children with Prader-Willi syndrome. J. Neurodev. Disord. 2017, 9, 18. [CrossRef]

97. Ramos-Molina, B.; Molina-Vega, M.; Fernández-García, J.C.; Creemers, J.W. Hyperphagia and Obesity in Prader-Willi Syndrome: PCSK1 Deficiency and Beyond? Genes (Basel) 2018, 9, 288. [CrossRef]

98. Anagnostou, E.; Zwaigenbaum, L.; Szatmari, P.; Fombonne, E.; Fernandez, B.A.; Woodbury-Smith, M.; Brian, J.; Bryson, S.; Smith, I.M.; Drmic, I.; et al. Autism spectrum disorder: advances in evidence-based practice. CMAJ 2014, 186, 509-519. [CrossRef] [PubMed]

99. Linke, A.C.; Olson, L.; Gao, Y.; Fishman, I.; Müller, R.-A. Psychotropic medication use in autism spectrum disorders may affect functional brain connectivity. Biol. Psychiatry Cogn. Neurosci. Neuroimaging 2017, 2, 518-527. [CrossRef] [PubMed]

100. Nihalani, N.; Schwartz, T.L.; Siddiqui, U.A.; Megna, J.L. Weight gain, obesity, and psychotropic prescribing. J. Obes. 2011, 2011, 893629. [CrossRef] [PubMed]

101. Coury, D.L.; Anagnostou, E.; Manning-Courtney, P.; Reynolds, A.; Cole, L.; McCoy, R.; Whitaker, A.; Perrin, J.M. Use of psychotropic medication in children and adolescents with autism spectrum disorders. Pediatrics 2012, 130, S69-S76. [CrossRef] [PubMed]

102. Frazier, T.W.; Shattuck, P.T.; Narendorf, S.C.; Cooper, B.P.; Wagner, M.; Spitznagel, E.L. Prevalence and correlates of psychotropic medication use in adolescents with an autism spectrum disorder with and without caregiver-reported attention-deficit/hyperactivity disorder. J. Child. Adolesc. Psychopharmacol. 2011, 21, 571-579. [CrossRef] [PubMed]

103. Spencer, D.; Marshall, J.; Post, B.; Kulakodlu, M.; Newschaffer, C.; Dennen, T.; Azocar, F.; Jain, A. Psychotropic medication use and polypharmacy in children with autism spectrum disorders. Pediatrics 2013, 132, 833-840. [CrossRef]

104. Jobski, K.; Höfer, J.; Hoffmann, F.; Bachmann, C. Use of psychotropic drugs in patients with autism spectrum disorders: A systematic review. Acta Psychiatr. Scand. 2017, 135, 8-28. [CrossRef]

105. Park, S.Y.; Cervesi, C.; Galling, B.; Molteni, S.; Walyzada, F.; Ameis, S.H.; Gerhard, T.; Olfson, M.; Correll, C.U. Antipsychotic use trends in youth with autism spectrum disorder and/or intellectual disability: A meta-analysis. J. Am. Acad. Child. Adolesc. Psychiatry 2016, 55, 456-468.e4. [CrossRef]

106. Fallah, M.S.; Shaikh, M.R.; Neupane, B.; Rusiecki, D.; Bennett, T.A.; Beyene, J. Atypical antipsychotics for irritability in pediatric autism: A systematic review and network meta-analysis. J. Child. Adolesc. Psychopharmacol. 2019, 29, 168-180. [CrossRef]

107. Fung, L.K.; Mahajan, R.; Nozzolillo, A.; Bernal, P.; Krasner, A.; Jo, B.; Coury, D.; Whitaker, A.; Veenstra-Vanderweele, J.; Hardan, A.Y. Pharmacologic Treatment of Severe Irritability and Problem Behaviors in Autism: A Systematic Review and Meta-analysis. Pediatrics 2016, 137, S124-135. [CrossRef]

108. Srisawasdi, P.; Vanwong, N.; Hongkaew, Y.; Puangpetch, A.; Vanavanan, S.; Intachak, B.; Ngamsamut, N.; Limsila, P.; Sukasem, C.; Kroll, M.H. Impact of risperidone on leptin and insulin in children and adolescents with autistic spectrum disorders. Clin. Biochem. 2017, 50, 678-685. [CrossRef] [PubMed]

109. Shimizu, H.; Shimomura, Y.; Hayashi, R.; Ohtani, K.; Sato, N.; Futawatari, T.; Mori, M. Serum leptin concentration is associated with total body fat mass, but not abdominal fat distribution. Int. J. Obes. Relat. Metab. Disord. 1997, 21, 536-541. [CrossRef] [PubMed]

110. Hirsch, L.E.; Pringsheim, T. Aripiprazole for autism spectrum disorders (ASD). Cochrane Database Syst. Rev. 2016, 6. [CrossRef] [PubMed]

111. Hsia, Y.; Wong, A.Y.S.; Murphy, D.G.M.; Simonoff, E.; Buitelaar, J.K.; Wong, I.C.K. Psychopharmacological prescriptions for people with autism spectrum disorder (ASD): A multinational study. Psychopharmacology 2014, 231, 999-1009. [CrossRef] [PubMed] 
112. Murray, M.L.; Hsia, Y.; Glaser, K.; Simonoff, E.; Murphy, D.G.M.; Asherson, P.J.; Eklund, H.; Wong, I.C.K. Pharmacological treatments prescribed to people with autism spectrum disorder (ASD) in primary health care. Psychopharmacology 2014, 231, 1011-1021. [CrossRef] [PubMed]

113. Bak, M.; Fransen, A.; Janssen, J.; van Os, J.; Drukker, M. Almost all antipsychotics result in weight gain: A meta-analysis. PLoS ONE 2014, 9, e94112. [CrossRef]

114. Meltzer, H.Y.; Massey, B.W. The role of serotonin receptors in the action of atypical antipsychotic drugs. Curr. Opin. Pharm. 2011, 11, 59-67. [CrossRef] [PubMed]

115. Roerig, J.L.; Steffen, K.J.; Mitchell, J.E. Atypical antipsychotic-induced weight gain: Insights into mechanisms of action. CNS Drugs 2011, 25, 1035-1059. [CrossRef]

116. Pringsheim, T.; Panagiotopoulos, C.; Davidson, J.; Ho, J. Evidence-based recommendations for monitoring safety of second-generation antipsychotics in children and youth. Paediatr. Child. Health 2011, 16, 581-589. [CrossRef]

117. Williams, K.; Brignell, A.; Randall, M.; Silove, N.; Hazell, P. Selective serotonin reuptake inhibitors (SSRIs) for autism spectrum disorders (ASD). Cochrane Database Syst. Rev. 2013, 8, CD004677. [CrossRef]

118. Reekie, J.; Hosking, S.P.M.; Prakash, C.; Kao, K.-T.; Juonala, M.; Sabin, M.A. The effect of antidepressants and antipsychotics on weight gain in children and adolescents: Antidepressants/psychotics and weight in youth. Obes. Rev. 2015, 16, 566-580. [CrossRef] [PubMed]

119. King, B.H.; Hollander, E.; Sikich, L.; McCracken, J.T.; Scahill, L.; Bregman, J.D.; Donnelly, C.L.; Anagnostou, E.; Dukes, K.; Sullivan, L.; et al. Lack of Efficacy of Citalopram in Children with Autism Spectrum Disorders and High Levels of Repetitive Behavior: Citalopram Ineffective in Children with Autism. Arch. Gen. Psychiatry 2009, 66, 583-590. [CrossRef] [PubMed]

120. Hollander, E.; Soorya, L.; Chaplin, W.; Anagnostou, E.; Taylor, B.P.; Ferretti, C.J.; Wasserman, S.; Swanson, E.; Settipani, C. A Double-Blind Placebo-Controlled Trial of Fluoxetine for Repetitive Behaviors and Global Severity in Adult Autism Spectrum Disorders. AJP 2012, 169, 292-299. [CrossRef] [PubMed]

121. Blumenthal, S.R.; Castro, V.M.; Clements, C.C.; Rosenfield, H.R.; Murphy, S.N.; Fava, M.; Weilburg, J.B.; Erb, J.L.; Churchill, S.E.; Kohane, I.S.; et al. An Electronic Health Records Study of Long-Term Weight Gain Following Antidepressant Use. JAMA Psychiatry 2014, 71, 889-896. [CrossRef] [PubMed]

122. Stolzer, J.M. Breastfeeding and obesity: A meta-analysis. Open J. Prev. Med. 2011, 1, 88-93. [CrossRef]

123. Tseng, P.-T.; Chen, Y.-W.; Stubbs, B.; Carvalho, A.F.; Whiteley, P.; Tang, C.-H.; Yang, W.-C.; Chen, T.-Y.; Li, D.-J.; $\mathrm{Chu}, \mathrm{C} .-\mathrm{S} . ;$ et al. Maternal breastfeeding and autism spectrum disorder in children: A systematic review and meta-analysis. Nutr. Neurosci. 2019, 22, 354-362. [CrossRef]

124. Boucher, O.; Julvez, J.; Guxens, M.; Arranz, E.; Ibarluzea, J.; Sánchez de Miguel, M.; Fernández-Somoano, A.; Tardon, A.; Rebagliato, M.; Garcia-Esteban, R.; et al. Association between breastfeeding duration and cognitive development, autistic traits and ADHD symptoms: A multicenter study in Spain. Pediatr. Res. 2017, 81, 434-442. [CrossRef]

125. Al-Farsi, Y.M.; Al-Sharbati, M.M.; Waly, M.I.; Al-Farsi, O.A.; Al-Shafaee, M.A.; Al-Khaduri, M.M.; Trivedi, M.S.; Deth, R.C. Effect of suboptimal breast-feeding on occurrence of autism: A case-control study. Nutrition 2012, 28, e27-32. [CrossRef]

126. Shafai, T.; Mustafa, M.; Hild, T.; Mulari, J.; Curtis, A. The association of early weaning and formula feeding with autism spectrum disorders. Breastfeed. Med. 2014, 9, 275-276. [CrossRef]

127. Steinman, G. Can the chance of having twins be modified by diet? Lancet 2006, 367, 1461-1462. [CrossRef]

128. Umer, A.; Hamilton, C.; Britton, C.M.; Mullett, M.D.; John, C.; Neal, W.; Lilly, C.L. Association between breastfeeding and childhood obesity: Analysis of a linked longitudinal study of rural Appalachian fifth-grade children. Child. Obes. 2015, 11, 449-455. [CrossRef] [PubMed]

129. Ortega-García, J.A.; Kloosterman, N.; Alvarez, L.; Tobarra-Sánchez, E.; Cárceles-Álvarez, A.; Pastor-Valero, R.; López-Hernández, F.A.; Sánchez-Solis, M.; Claudio, L. Full breastfeeding and obesity in children: A prospective study from birth to 6 years. Child. Obes. 2018, 14, 327-337. [CrossRef] [PubMed]

130. Yan, J.; Liu, L.; Zhu, Y.; Huang, G.; Wang, P.P. The association between breastfeeding and childhood obesity: A meta-analysis. BMC Public Health 2014, 14, 1267. [CrossRef] [PubMed]

131. Beccuti, G.; Pannain, S. Sleep and obesity. Curr. Opin. Clin. Nutr. Metab. Care 2011, 14, 402-412. [CrossRef] [PubMed]

132. Patel, S.R.; Hu, F.B. Short sleep duration and weight gain: A systematic review. Obesity (Silver Spring) 2008, 16, 643-653. [CrossRef] [PubMed] 
133. Chen, X.; Beydoun, M.A.; Wang, Y. Is Sleep Duration Associated with Childhood Obesity? A Systematic Review and Meta-analysis. Obesity 2008, 16, 265-274. [CrossRef]

134. Fatima, Y.; Doi, S.A.; Mamun, A.A. Sleep quality and obesity in young subjects: A meta-analysis. Obes. Rev. 2016, 17, 1154-1166. [CrossRef]

135. Knutson, K.L. Does inadequate sleep play a role in vulnerability to obesity? Am. J. Hum. Biol. 2012, 24, 361-371. [CrossRef]

136. Chaput, J.-P.; Lambert, M.; Gray-Donald, K.; McGrath, J.J.; Tremblay, M.S.; O’Loughlin, J.; Tremblay, A. Short Sleep Duration Is Independently Associated with Overweight and Obesity in Quebec Children. Can. J. Public Health 2011, 102, 369-374.

137. Narang, I.; Mathew, J.L. Childhood obesity and obstructive sleep apnea. J. Nutr. Metab. 2012, $2012,134202$. [CrossRef]

138. Maxwell-Horn, A.; Malow, B.A. Sleep in Autism. Semin. Neurol. 2017, 37, 413-418. [PubMed]

139. Zuckerman, K.E.; Hill, A.P.; Guion, K.; Voltolina, L.; Fombonne, E. Overweight and Obesity: Prevalence and Correlates in a Large Clinical Sample of Children with Autism Spectrum Disorder. J. Autism Dev. Disord. 2014, 44, 1708-1719. [CrossRef] [PubMed]

140. Elrod, M.G.; Nylund, C.M.; Susi, A.L.; Gorman, G.H.; Hisle-Gorman, E.; Rogers, D.J.; Erdie-Lalena, C. Prevalence of Diagnosed Sleep Disorders and Related Diagnostic and Surgical Procedures in Children with Autism Spectrum Disorders. J. Dev. Behav. Pediatr. 2016, 37, 377-384. [CrossRef] [PubMed]

141. Bresnahan, M.; Hornig, M.; Schultz, A.F.; Gunnes, N.; Hirtz, D.; Lie, K.K.; Magnus, P.; Reichborn-Kjennerud, T.; Roth, C.; Schjølberg, S.; et al. Association of maternal report of infant and toddler gastrointestinal symptoms with autism: Evidence from a prospective birth cohort. JAMA Psychiatry 2015, 72, 466-474. [CrossRef] [PubMed]

142. McElhanon, B.O.; McCracken, C.; Karpen, S.; Sharp, W.G. Gastrointestinal Symptoms in Autism Spectrum Disorder: A Meta-analysis. Pediatrics 2014, 133, 872-883. [CrossRef] [PubMed]

143. Prosperi, M.; Santocchi, E.; Balboni, G.; Narzisi, A.; Bozza, M.; Fulceri, F.; Apicella, F.; Igliozzi, R.; Cosenza, A.; Tancredi, R.; et al. Behavioral phenotype of ASD preschoolers with gastrointestinal symptoms or food selectivity. J. Autism Dev. Disord. 2017, 47, 3574-3588. [CrossRef]

144. Mazefsky, C.A.; Borue, X.; Day, T.N.; Minshew, N.J. Emotion Regulation Patterns in Adolescents with High-Functioning Autism Spectrum Disorder: Comparison to Typically Developing Adolescents and Association With Psychiatric Symptoms. Autism Res. 2014, 7, 344-354. [CrossRef] [PubMed]

145. Mayer, E.A.; Padua, D.; Tillisch, K. Altered brain-gut axis in autism: Comorbidity or causative mechanisms? Bioessays 2014, 36, 933-939. [CrossRef]

146. Strati, F.; Cavalieri, D.; Albanese, D.; De Felice, C.; Donati, C.; Hayek, J.; Jousson, O.; Leoncini, S.; Renzi, D.; Calabrò, A.; et al. New evidences on the altered gut microbiota in autism spectrum disorders. Microbiome 2017, 5, 24. [CrossRef]

147. Williams, B.L.; Hornig, M.; Buie, T.; Bauman, M.L.; Paik, M.C.; Wick, I.; Bennett, A.; Jabado, O.; Hirschberg, D.L.; Lipkin, W.I. Impaired carbohydrate digestion and transport and mucosal dysbiosis in the intestines of children with autism and gastrointestinal disturbances. PLoS ONE 2011, 6, e24585. [CrossRef]

148. Zhang, M.; Ma, W.; Zhang, J.; He, Y.; Wang, J. Analysis of gut microbiota profiles and microbe-disease associations in children with autism spectrum disorders in China. Sci. Rep. 2018, 8, 13981. [CrossRef] [PubMed]

149. Chakraborti, C.K. New-found link between microbiota and obesity. World J. Gastrointest. Pathophysiol. 2015, 6, 110-119. [CrossRef] [PubMed]

150. Koliada, A.; Syzenko, G.; Moseiko, V.; Budovska, L.; Puchkov, K.; Perederiy, V.; Gavalko, Y.; Dorofeyev, A.; Romanenko, M.; Tkach, S.; et al. Association between body mass index and firmicutes/bacteroidetes ratio in an adult Ukrainian population. BMC Microbiol. 2017, 17, 120. [CrossRef] [PubMed]

151. Indiani, C.M.D.S.P.; Rizzardi, K.F.; Castelo, P.M.; Ferraz, L.F.C.; Darrieux, M.; Parisotto, T.M. Childhood obesity and firmicutes/bacteroidetes ratio in the gut microbiota: A systematic review. Child. Obes. 2018, 14, 501-509. [CrossRef] [PubMed]

152. Ley, R.E.; Bäckhed, F.; Turnbaugh, P.; Lozupone, C.A.; Knight, R.D.; Gordon, J.I. Obesity alters gut microbial ecology. Proc. Natl. Acad. Sci. USA 2005, 102, 11070-11075. [CrossRef] [PubMed] 
153. Murphy, E.F.; Cotter, P.D.; Healy, S.; Marques, T.M.; O'Sullivan, O.; Fouhy, F.; Clarke, S.F.; O'Toole, P.W.; Quigley, E.M.; Stanton, C.; et al. Composition and energy harvesting capacity of the gut microbiota: Relationship to diet, obesity and time in mouse models. Gut 2010, 59, 1635-1642. [CrossRef]

154. Bäckhed, F.; Roswall, J.; Peng, Y.; Feng, Q.; Jia, H.; Kovatcheva-Datchary, P.; Li, Y.; Xia, Y.; Xie, H.; Zhong, H.; et al. Dynamics and stabilization of the human gut microbiome during the first year of life. Cell Host Microbe 2015, 17, 690-703. [CrossRef]

155. Liu, F.; Li, J.; Wu, F.; Zheng, H.; Peng, Q.; Zhou, H. Altered composition and function of intestinal microbiota in autism spectrum disorders: A systematic review. Transl. Psychiatry 2019, 9, 43. [CrossRef]

156. Sharon, G.; Cruz, N.J.; Kang, D.-W.; Gandal, M.J.; Wang, B.; Kim, Y.-M.; Zink, E.M.; Casey, C.P.; Taylor, B.C.; Lane, C.J.; et al. Human Gut Microbiota from Autism Spectrum Disorder Promote Behavioral Symptoms in Mice. Cell 2019, 177, 1600-1618. [CrossRef]

157. Jazani, N.H.; Savoj, J.; Lustgarten, M.; Lau, W.L.; Vaziri, N.D. Impact of gut dysbiosis on neurohormonal pathways in chronic kidney disease. Diseases 2019, 7, 21. [CrossRef]

158. Siniscalco, D.; Brigida, A.L.; Antonucci, N. Autism and neuro-immune-gut link. Molecular 2018, 5, $166-172$. [CrossRef]

159. Siniscalco, D.; Schultz, S.; Brigida, A.L.; Antonucci, N. Inflammation and Neuro-Immune Dysregulations in Autism Spectrum Disorders. Pharmaceuticals 2018, 11, 56. [CrossRef] [PubMed]

160. Fiorentino, M.; Sapone, A.; Senger, S.; Camhi, S.S.; Kadzielski, S.M.; Buie, T.M.; Kelly, D.L.; Cascella, N.; Fasano, A. Blood-brain barrier and intestinal epithelial barrier alterations in autism spectrum disorders. Mol. Autism 2016, 7, 49. [CrossRef] [PubMed]

161. Cani, P.D.; Amar, J.; Iglesias, M.A.; Poggi, M.; Knauf, C.; Bastelica, D.; Neyrinck, A.M.; Fava, F.; Tuohy, K.M.; Chabo, C.; et al. Metabolic endotoxemia initiates obesity and insulin resistance. Diabetes 2007, 56, 1761-1772. [CrossRef]

162. Boulangé, C.L.; Neves, A.L.; Chilloux, J.; Nicholson, J.K.; Dumas, M.-E. Impact of the gut microbiota on inflammation, obesity, and metabolic disease. Genome Med. 2016, 8, 42. [CrossRef]

163. Kang, Y.; Cai, Y. Gut microbiota and obesity: Implications for fecal microbiota transplantation therapy. Hormones (Athens) 2017, 16, 223-234. [CrossRef]

164. Esnafoglu, E.; Cırrık, S.; Ayyıldız, S.N.; Erdil, A.; Ertürk, E.Y.; Daglı, A.; Noyan, T. Increased Serum Zonulin Levels as an Intestinal Permeability Marker in Autistic Subjects. J. Pediatr. 2017, 188, 240-244. [CrossRef]

165. De Magistris, L.; Familiari, V.; Pascotto, A.; Sapone, A.; Frolli, A.; Iardino, P.; Carteni, M.; De Rosa, M.; Francavilla, R.; Riegler, G.; et al. Alterations of the intestinal barrier in patients with autism spectrum disorders and in their first-degree relatives. J. Pediatr. Gastroenterol. Nutr. 2010, 51, 418-424. [CrossRef]

166. Kushak, R.I.; Buie, T.M.; Murray, K.F.; Newburg, D.S.; Chen, C.; Nestoridi, E.; Winter, H.S. Evaluation of Intestinal Function in Children with Autism and Gastrointestinal Symptoms. J. Pediatr. Gastroenterol. Nutr. 2016, 62, 687-691. [CrossRef]

167. Adams, J.B.; Johansen, L.J.; Powell, L.D.; Quig, D.; Rubin, R.A. Gastrointestinal flora and gastrointestinal status in children with autism-comparisons to typical children and correlation with autism severity. BMC Gastroenterol. 2011, 11, 22. [CrossRef]

168. Morrison, D.J.; Preston, T. Formation of short chain fatty acids by the gut microbiota and their impact on human metabolism. Gut Microbes 2016, 7, 189-200. [CrossRef] [PubMed]

169. Valdes, A.M.; Walter, J.; Segal, E.; Spector, T.D. Role of the gut microbiota in nutrition and health. BMJ 2018, 361, k2179. [CrossRef] [PubMed]

170. Yang, J.; Wang, H.-P.; Zhou, L.; Xu, C.-F. Effect of dietary fiber on constipation: A meta analysis. World J. Gastroenterol. 2012, 18, 7378-7383. [CrossRef] [PubMed]

171. Zou, J.; Chassaing, B.; Singh, V.; Pellizzon, M.; Ricci, M.; Fythe, M.D.; Kumar, M.V.; Gewirtz, A.T. Fiber-Mediated Nourishment of Gut Microbiota Protects against Diet-Induced Obesity by Restoring IL-22-Mediated Colonic Health. Cell Host Microbe 2018, 23, 41-53. [CrossRef] [PubMed]

172. Deehan, E.C.; Walter, J. The Fiber Gap and the Disappearing Gut Microbiome: Implications for Human Nutrition. Trends Endocrinol. Metab. 2016, 27, 239-242. [CrossRef] [PubMed]

173. Larraufie, P.; Martin-Gallausiaux, C.; Lapaque, N.; Dore, J.; Gribble, F.M.; Reimann, F.; Blottiere, H.M. SCFAs strongly stimulate PYY production in human enteroendocrine cells. Sci. Rep. 2018, 8, 74. [CrossRef] [PubMed] 
174. Willemsen, L.E.M.; Koetsier, M.A.; van Deventer, S.J.H.; van Tol, E.A. Short chain fatty acids stimulate epithelial mucin 2 expression through differential effects on prostaglandin $\mathrm{E}(1)$ and $\mathrm{E}(2)$ production by intestinal myofibroblasts. Gut 2003, 52, 1442-1447. [CrossRef]

175. Macia, L.; Tan, J.; Vieira, A.T.; Leach, K.; Stanley, D.; Luong, S.; Maruya, M.; Ian McKenzie, C.; Hijikata, A.; Wong, C.; et al. Metabolite-sensing receptors GPR43 and GPR109A facilitate dietary fibre-induced gut homeostasis through regulation of the inflammasome. Nat. Commun. 2015, 6, 6734. [CrossRef]

176. Mirmonsef, P.; Zariffard, M.R.; Gilbert, D.; Makinde, H.; Landay, A.L.; Spear, G.T. Short Chain Fatty Acids Induce Pro-Inflammatory Cytokine Production Alone and in Combination with Toll-like Receptor Ligands. Am. J. Reprod. Immunol. 2012, 67, 391-400. [CrossRef]

177. Chambers, E.S.; Viardot, A.; Psichas, A.; Morrison, D.J.; Murphy, K.G.; Zac-Varghese, S.E.K.; MacDougall, K.; Preston, T.; Tedford, C.; Finlayson, G.S.; et al. Effects of targeted delivery of propionate to the human colon on appetite regulation, body weight maintenance and adiposity in overweight adults. Gut 2015, 64, 1744-1754. [CrossRef]

178. De Vadder, F.; Kovatcheva-Datchary, P.; Goncalves, D.; Vinera, J.; Zitoun, C.; Duchampt, A.; Bäckhed, F.; Mithieux, G. Microbiota-generated metabolites promote metabolic benefits via gut-brain neural circuits. Cell 2014, 156, 84-96. [CrossRef] [PubMed]

179. Zmora, N.; Soffer, E.; Elinav, E. Transforming medicine with the microbiome. Sci. Transl. Med. 2019, 11, eaaw1815. [CrossRef] [PubMed]

180. Ahima, R.S. Revisiting leptin's role in obesity and weight loss. J. Clin. Invest. 2008, 118, 2380-2383. [CrossRef] [PubMed]

181. Klein, S.; Coppack, S.W.; Mohamed-Ali, V.; Landt, M. Adipose tissue leptin production and plasma leptin kinetics in humans. Diabetes 1996, 45, 984-987. [CrossRef] [PubMed]

182. Park, H.-K.; Ahima, R.S. Physiology of leptin: Energy homeostasis, neuroendocrine function and metabolism. Metabolism 2015, 64, 24-34. [CrossRef] [PubMed]

183. Mazor, R.; Friedmann-Morvinski, D.; Alsaigh, T.; Kleifeld, O.; Kistler, E.B.; Rousso-Noori, L.; Huang, C.; Li, J.B.; Verma, I.M.; Schmid-Schönbein, G.W. Cleavage of the leptin receptor by matrix metalloproteinase-2 promotes leptin resistance and obesity in mice. Sci. Transl. Med. 2018, 10, eaah6324. [CrossRef] [PubMed]

184. Myers, M.G.; Leibel, R.L.; Seeley, R.J.; Schwartz, M.W. Obesity and leptin resistance: Distinguishing cause from effect. Trends Endocrinol. Metab. 2010, 21, 643-651. [CrossRef] [PubMed]

185. Al-Zaid, F.S.; Alhader, A.A.; Al-Ayadhi, L.Y. Altered ghrelin levels in boys with autism: A novel finding associated with hormonal dysregulation. Sci. Rep. 2014, 4, 6478. [CrossRef]

186. Rodrigues, D.H.; Rocha, N.P.; Sousa, L.F.; Barbosa, I.G.; Kummer, A.; Teixeira, A.L. Changes in adipokine levels in autism spectrum disorders. Neuropsychobiology 2014, 69, 6-10. [CrossRef]

187. Raghavan, R.; Zuckerman, B.; Hong, X.; Wang, G.; Yuelong, J.; Paige, D.; DiBari, J.; Zhang, C.; Fallin, M.D.; Wang, X. Fetal and infancy growth pattern, cord and early childhood plasma leptin, and development of autism spectrum disorder in the Boston birth cohort. Autism Res. 2018, 11, 1416-1431. [CrossRef]

188. Hasan, Z.A.; Al-Kafaji, G.; Al-Sherawi, M.I.; Razzak, R.A.; Eltayeb, D.; Skrypnk, C.; Bakhiet, M. Investigation of serum levels of leptin, ghrelin and growth hormone in Bahraini children with autism. Int. Arch. Transl. Med. 2019, 5, 7. [CrossRef]

189. Chawarska, K.; Campbell, D.; Chen, L.; Shic, F.; Klin, A.; Chang, J. Early Generalized Overgrowth in Boys with Autism. Arch. Gen. Psychiatry 2011, 68, 1021-1031. [CrossRef] [PubMed]

190. Lihn, A.S.; Pedersen, S.B.; Richelsen, B. Adiponectin: Action, regulation and association to insulin sensitivity. Obes. Rev. 2005, 6, 13-21. [CrossRef] [PubMed]

191. Arita, Y.; Kihara, S.; Ouchi, N.; Takahashi, M.; Maeda, K.; Miyagawa, J.; Hotta, K.; Shimomura, I.; Nakamura, T.; Miyaoka, K.; et al. Paradoxical decrease of an adipose-specific protein, adiponectin, in obesity. Biochem. Biophys. Res. Commun. 1999, 257, 79-83. [CrossRef] [PubMed]

192. Ouchi, N.; Walsh, K. Adiponectin as an anti-inflammatory factor. Clin. Chim. Acta 2007, 380, 24-30. [CrossRef] [PubMed]

193. Kawano, J.; Arora, R. The role of adiponectin in obesity, diabetes, and cardiovascular disease. J. Cardiometab. Syndr. 2009, 4, 44-49. [CrossRef]

194. Achari, A.E.; Jain, S.K. Adiponectin, a Therapeutic Target for Obesity, Diabetes, and Endothelial Dysfunction. Int. J. Mol. Sci. 2017, 18, 1321. [CrossRef] 
195. Ghaffari, M.A.; Mousavinejad, E.; Riahi, F.; Mousavinejad, M.; Afsharmanesh, M.R. Increased Serum Levels of Tumor Necrosis Factor-Alpha, Resistin, and Visfatin in the Children with Autism Spectrum Disorders: A Case-Control Study. Neurol. Res. Int. 2016, 2016, 7. [CrossRef]

196. Fujita-Shimizu, A.; Suzuki, K.; Nakamura, K.; Miyachi, T.; Matsuzaki, H.; Kajizuka, M.; Shinmura, C.; Iwata, Y.; Suda, S.; Tsuchiya, K.J.; et al. Decreased serum levels of adiponectin in subjects with autism. Prog. Neuropsychopharmacol. Biol. Psychiatry 2010, 34, 455-458. [CrossRef]

197. Raghavan, R.; Fallin, M.D.; Hong, X.; Wang, G.; Ji, Y.; Stuart, E.A.; Paige, D.; Wang, X. Cord and Early Childhood Plasma Adiponectin Levels and Autism Risk: A Prospective Birth Cohort Study. J. Autism Dev. Disord. 2019, 49, 173-184. [CrossRef]

198. Song, H.J.; Oh, S.; Quan, S.; Ryu, O.-H.; Jeong, J.-Y.; Hong, K.-S.; Kim, D.-H. Gender differences in adiponectin levels and body composition in older adults: Hallym aging study. BMC Geriatr. 2014, 14, 8. [CrossRef] [PubMed]

199. Ohman-Hanson, R.A.; Cree-Green, M.; Kelsey, M.M.; Bessesen, D.H.; Sharp, T.A.; Pyle, L.; Pereira, R.I.; Nadeau, K.J. Ethnic and Sex Differences in Adiponectin: From Childhood to Adulthood. J. Clin. Endocrinol. Metab. 2016, 101, 4808-4815. [CrossRef] [PubMed]

200. Rueda-Clausen, C.F.; Lahera, V.; Calderón, J.; Bolivar, I.C.; Castillo, V.R.; Gutiérrez, M.; Carreño, M.; Oubiña, M.d.P.; Cachofeiro, V.; López-Jaramillo, P. The presence of abdominal obesity is associated with changes in vascular function independently of other cardiovascular risk factors. Int. J. Cardiol. 2010, 139, 32-41. [CrossRef] [PubMed]

201. Cummings, D.E.; Shannon, M.H. Roles for Ghrelin in the Regulation of Appetite and Body Weight. Arch. Surg. 2003, 138, 389-396. [CrossRef] [PubMed]

202. Makris, C.M.; Alexandrou, A.; Papatsoutsos, G.E.; Malietzis, G.; Tsilimigras, I.D.; Guerron, D.A.; Moris, D. Ghrelin and obesity: Identifying gaps and dispelling myth a reappraisal. Vivo 2017, 31, 1047-1050.

203. Lebenthal, Y.; Gat-Yablonski, G.; Shtaif, B.; Padoa, A.; Phillip, M.; Lazar, L. Effect of sex hormone administration on circulating ghrelin levels in peripubertal children. J. Clin. Endocrinol. Metab. 2006, 91, 328-331. [CrossRef] [PubMed]

204. Sanchez, C.E.; Barry, C.; Sabhlok, A.; Russell, K.; Majors, A.; Kollins, S.H.; Fuemmeler, B.F. Maternal pre-pregnancy obesity and child neurodevelopmental outcomes: A meta-analysis. Obes. Rev. 2018, 19, 464-484. [CrossRef]

205. Li, Y.-M.; Ou, J.-J.; Liu, L.; Zhang, D.; Zhao, J.-P.; Tang, S.-Y. Association Between Maternal Obesity and Autism Spectrum Disorder in Offspring: A Meta-analysis. J. Autism Dev. Disord. 2016, 46, 95-102. [CrossRef]

206. Xu, G.; Jing, J.; Bowers, K.; Liu, B.; Bao, W. Maternal Diabetes and the Risk of Autism Spectrum Disorders in the Offspring: A Systematic Review and Meta-Analysis. J. Autism Dev. Disord. 2014, 44, 766-775. [CrossRef]

207. Wan, H.; Zhang, C.; Li, H.; Luan, S.; Liu, C. Association of maternal diabetes with autism spectrum disorders in offspring. Medicine (Baltimore) 2018, 97, e9438. [CrossRef]

208. Krakowiak, P.; Walker, C.K.; Bremer, A.A.; Baker, A.S.; Ozonoff, S.; Hansen, R.L.; Hertz-Picciotto, I. Maternal metabolic conditions and risk for autism and other neurodevelopmental disorders. Pediatrics 2012, 129, e1121-e1128. [CrossRef] [PubMed]

209. Eidelman, A.I.; Samueloff, A. The pathophysiology of the fetus of the diabetic mother. Semin. Perinatol. 2002, 26, 232-236. [CrossRef] [PubMed]

210. Burstyn, I.; Wang, X.; Yasui, Y.; Sithole, F.; Zwaigenbaum, L. Autism spectrum disorders and fetal hypoxia in a population-based cohort: Accounting for missing exposures via Estimation-Maximization algorithm. BMC Med. Res. Methodol. 2011, 11, 2. [CrossRef] [PubMed]

211. Kolevzon, A.; Gross, R.; Reichenberg, A. Prenatal and Perinatal Risk Factors for Autism: A Review and Integration of Findings. Arch. Pediatr. Adolesc. Med. 2007, 161, 326-333. [CrossRef] [PubMed]

212. Ming, X.; Stein, T.P.; Brimacombe, M.; Johnson, W.G.; Lambert, G.H.; Wagner, G.C. Increased excretion of a lipid peroxidation biomarker in autism. Prostaglandins Leukot. Essent. Fat. Acids 2005, 73, 379-384. [CrossRef] [PubMed]

213. Chen, X.; Scholl, T.O. Oxidative stress: Changes in pregnancy and with gestational diabetes mellitus. Curr. Diab. Rep. 2005, 5, 282-288. [CrossRef]

214. Onore, C.; Careaga, M.; Ashwood, P. The role of immune dysfunction in the pathophysiology of autism. Brain Behav. Immun. 2012, 26, 383-392. [CrossRef] 
215. Kawasaki, M.; Arata, N.; Miyazaki, C.; Mori, R.; Kikuchi, T.; Ogawa, Y.; Ota, E. Obesity and abnormal glucose tolerance in offspring of diabetic mothers: A systematic review and meta-analysis. PLoS ONE 2018, 13, e0190676. [CrossRef]

216. Deierlein, A.L.; Siega-Riz, A.M.; Chantala, K.; Herring, A.H. The Association Between Maternal Glucose Concentration and Child BMI at Age 3 Years. Diabetes Care 2011, 34, 480-484. [CrossRef]

217. Lawlor, D.A.; Lichtenstein, P.; Långström, N. Association of maternal diabetes mellitus in pregnancy with offspring adiposity into early adulthood: Sibling study in a prospective cohort of 280,866 men from 248,293 families. Circulation 2011, 123, 258-265. [CrossRef]

218. Ash, T.; Agaronov, A.; Young, T.; Aftosmes-Tobio, A.; Davison, K.K. Family-based childhood obesity prevention interventions: A systematic review and quantitative content analysis. Int. J. Behav. Nutr. Phys. Act. 2017, 14, 113. [CrossRef] [PubMed]

219. Bennett, E.A.; Kolko, R.; Chia, L.; Elliott, J.P.; Kalarchian, M.A. Treatment of Obesity among Youth with Intellectual and Developmental Disabilities: An Emerging Role for Telenursing. West. J. Nurs. Res. 2017, 39, 1008-1027. [CrossRef] [PubMed]

220. Freemark, M. Pharmacotherapy of Childhood Obesity: An evidence-based, conceptual approach. Diabetes Care 2007, 30, 395-402. [CrossRef] [PubMed]

221. Heck, A.M.; Yanovski, J.A.; Calis, K.A. Orlistat, a new lipase inhibitor for the management of obesity. Pharmacotherapy 2000, 20, 270-279. [CrossRef] [PubMed]

222. Wang, L.W.; Tancredi, D.J.; Thomas, D.W. The prevalence of gastrointestinal problems in children across the United States with autism spectrum disorders from families with multiple affected members. J. Dev. Behav. Pediatr. 2011, 32, 351-360. [CrossRef] [PubMed]

223. Mohammed, M.A.; Moles, R.J.; Chen, T.F. Medication-related burden and patients' lived experience with medicine: A systematic review and metasynthesis of qualitative studies. BMJ Open 2016, 6, e010035. [CrossRef]

224. Taylor, V.H. Implementing antiobesity treatment in a patient with a mood disorder. J. Psychiatry Neurosci. 2008, 33, E1-E2. [PubMed]

225. Canoy, D.; Yang, T.O. Obesity in children: Bariatric surgery. BMJ Clin. Evid. 2015, 2015, 325.

226. Bochukova, E.G.; Huang, N.; Keogh, J.; Henning, E.; Purmann, C.; Blaszczyk, K.; Saeed, S.; Hamilton-Shield, J.; Clayton-Smith, J.; O'Rahilly, S.; et al. Large, rare chromosomal deletions associated with severe early-onset obesity. Nature 2010, 463, 666-670. [CrossRef]

227. Inge, T.H.; Courcoulas, A.P.; Jenkins, T.M.; Michalsky, M.P.; Brandt, M.L.; Xanthakos, S.A.; Dixon, J.B.; Harmon, C.M.; Chen, M.K.; Xie, C.; et al. Five-Year Outcomes of Gastric Bypass in Adolescents as Compared with Adults. N. Engl. J. Med. 2019, 380, 2136-2145. [CrossRef]

228. Maiano, M.C.; Normand, C.L.; Aime, A.; Begarie, J. Lifestyle interventions targeting changes in body weight and composition among youth with an intellectual disability: A systematic review. Res. Dev. Disabil. 2014, 35, 1914-1926. [CrossRef] [PubMed]

229. Styne, D.M.; Arslanian, S.A.; Connor, E.L.; Farooqi, I.S.; Murad, M.H.; Silverstein, J.H.; Yanovski, J.A. Pediatric obesity-Assessment, treatment, and prevention: An endocrine society clinical practice guideline. J. Clin. Endocrinol. Metab. 2017, 102, 709-757. [CrossRef] [PubMed]

(C) 2019 by the authors. Licensee MDPI, Basel, Switzerland. This article is an open access article distributed under the terms and conditions of the Creative Commons Attribution (CC BY) license (http://creativecommons.org/licenses/by/4.0/). 